\title{
High temperature (HT) polymer electrolyte membrane fuel cells (PEMFC) - A review
}

Amrit Chandan, Mariska Hattenberger, Ahmad El-kharouf, Shangfeng Du, Aman Dhir, Valerie Self, Bruno G. Pollet, Andrew Ingram and Waldemar Bujalski

\begin{abstract}
One possible solution of combating issues posed by climate change is the use of the High Temperature (HT) Polymer Electrolyte Membrane (PEM) Fuel Cell (FC) in some applications. The typical HT-PEMFC operating temperatures are in the range of $100 e 200 \mathrm{O} \mathrm{C}$ which allows for co-generation of heat and power, high tolerance to fuel impurities and simpler system design. This paper reviews the current literature concerning the HT-PEMFC, ranging from cell materials to stack and stack testing. Only acid doped PBI membranes meet the US DOE (Department of Energy) targets for high temperature membranes operating under no humidification on both anode and cathode sides (barring the durability). This eliminates the stringent requirement for humidity however, they have many potential drawbacks including increased degradation, leaching of acid and incompatibility with current state-of-the-art fuel cell materials. In this type of fuel cell, the choice of membrane material determines the other fuel cell component material composition, for example when using an acid doped system, the flow field plate material must be carefully selected to take into account the advanced degradation. Novel research is required in all aspects of the fuel cell components in order to ensure that they meet stringent durability requirements for mobile applications.
\end{abstract}

\section{Introduction}

Greenhouse gas emissions are ever increasing in an age where hydrocarbon (gas, oil and coal) based power generators dominate. This is especially an issue when taking into consideration that our remaining reserves of oil and natural gas are rapidly dwindling as world population increases ( 7 billion at present). One way of combating our impact on the world is through the adoption of a Hydrogen Economy. This could be achieved through the use of Hydrogen Fuel Cells (HFCs) as energy converting devices whereby electricity and heat are produced in the electrochemical process with water as the only waste product.

PEMFCs are ideally suited for transport [1], Combined Heat And Power (CHP) and mobile auxiliary power applications. Among the many attractive features, the high power density, 
rapid start up and high efficiency makes the PEMFC the system of choice for the transport manufacturers. The aforementioned features are further enhanced when combined with their simple modular design [2], low weight and the stationary electrolyte in the form of a solid polymer membrane [3]. There have been many advances in the development of low temperature PEMFC (LT-PEMFC), for example power densities have increased when varying the electrode assembly methodology.

Power densities increased from approximately $93 \mathrm{~mW} \mathrm{~cm}^{-2}$ at $0.6 \mathrm{~V}$ when using the PTFE bound method to $147 \mathrm{~mW} \mathrm{~cm}^{-2}$ at $0.6 \mathrm{~V}$ when using a thin film transfer method [4]. Higher power densities of $233 \mathrm{~mW} \mathrm{~cm}^{-2}$ have been achieved by using commercially available electrodes [5]. Recent studies shows that power densities of $680 \mathrm{~mW} \mathrm{~cm}^{-2}$ can be achieved [6] for LT-PEMFC. A power density of $100 \mathrm{~mW} \mathrm{~cm}{ }^{-2}$ at $160{ }^{\circ} \mathrm{C}$ was obtained when using a commercial HT- PEM CELTEC-P10oo MEA produced by BASF [7]. This is a much lower power density than that found for the LT-PEM electrodes because of the large activation loss found with the use of acid based membranes.

Also the catalyst loadings have been significantly reduced by 10 and even 100 -fold by the 1980's and thus the overall cost of the LT-PEMFC has decreased, however, there are disadvantages to using this system. For example, the LT-PEMFC has a very low tolerance to impurities in fuel, thus requiring $99.99999 \%$ pure hydrogen which is costly to produce. The heat produced from the LT-PEMFC is also of a low temperature and thus is difficult to transfer away for use in other processes and due to the nature of the membrane, a water management system is needed to prevent flooding/drying out of the MEA, both of which lead to a loss in performance. These issues can be overcome through the use of an HTPEMFC.

The HT-PEMFC ( $\left.100{ }^{\circ} \mathrm{Ce} 2 \mathrm{OO}^{\circ} \mathrm{C}\right)$ variant is able to overcome all of these issues as current systems are able to operate without humidity, tolerate impure fuel streams and the high temperature waste heat can be easily utilised for other processes (e.g. cogeneration of heat and power or on-board reforming). These factors result in increased efficiency and simplification of the system.

This review focuses on recent advances in the component technologies for high temperature operation. The Gas Diffusion Electrode (GDE) incorporating the catalyst metal along with the Polymer Electrolyte Membrane (PEM) is situated at the heart of the fuel cell in the Membrane Electrode Assembly (MEA). Research into HT-PEMFCs has increased in the last few years, with around 140 papers published on the topic in 2011, mostly on the development of novel membranes. So far, on either side of the temperature scale, Nafion ${ }^{\circledR}$ and polybenzimidazole doped polymeric membranes with phosphoric acid $\left(\mathrm{PBI} / \mathrm{H}_{3} \mathrm{PO}_{4}\right)$ are the most efficient proton conducting membranes as shown in Fig. 1 [1]. 
The temperature range of $80 \mathrm{o} 130^{\circ} \mathrm{C}$ is the domain of many novel materials including composites and blends of conventional materials. The greatly varied class of polyaromatic hydrocarbons span the low temperature (LT) and intermediate temperature (IT) ranges.

The next two sections briefly discuss the benefits and disadvantages of higher temperature PEMFCs. Following that, proton exchange membranes, catalysts, gas diffusion layers and flow field plates are discussed with emphasis on recent advances for higher temperature applications. In the remaining sections the production of membrane electrode assemblies and stack design is described. The final sections are devoted to degradation studies.

\section{Advantages and disadvantages}

By switching to high temperature operation, theoretical and experimental analysis [8] have shown the following benefits:

\subsection{Electrode reaction kinetics}

In the LT-PEMFC, the Oxygen Reduction Reaction (ORR) has the slowest electrochemical kinetics and thus is the determining factor in the overall reaction rate. As a result of the slow reaction kinetics, the overpotential at the cathode is responsible for the cell voltage losses of the LT-PEMFC. By switching to higher temperatures, the ORR reaction rate is significantly increased [8], thus improving the performance of the PEMFC as a whole.

\subsection{CO tolerance}

The primary catalyst in LT-PEMFC is platinum, which has a significant affinity for carbon monoxide (CO) which is a by-product of reformation [9]. As a result, trace levels of carbon monoxide can cause a large decrease in the performance of the LT-PEMFC due to poisoning effect. HT-PEMFCs avoid this problem, at operating temperatures above $150{ }^{\circ} \mathrm{C}$, the affinity for carbon monoxide is reduced and $\mathrm{CO}$ tolerance is increased. For example, below $80^{\circ} \mathrm{C} \mathrm{CO}$ adsorbs onto the platinum catalyst in the electrode and severely affects the performance $[2,10 \mathrm{e} 13]$ but above $160{ }^{\circ} \mathrm{C}$ up to $3 \% \mathrm{CO}$ can be tolerated in the fuel stream [14e16]. This offers a significant advantage as many stages of fuel processing and gas cleaning can be removed thus allowing for cost-effective fuel.

\subsection{Heat and water management}

In the LT-PEMFC, 40e50\% of the energy is produced as heat which must be removed quickly from the fuel cell otherwise the fuel cell will over heat causing increased degradation of the materials. 


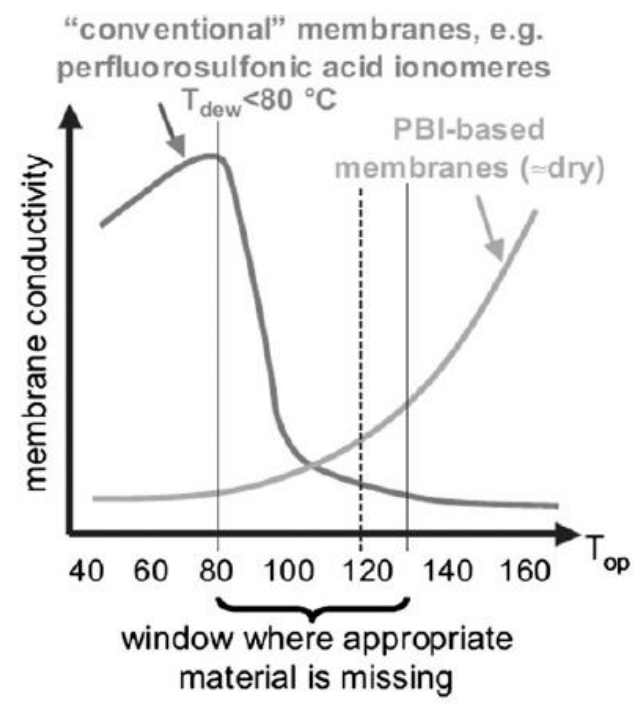

Fig. $1.80^{\circ} \mathrm{C}-130^{\circ} \mathrm{C}$ conductivity window [1].

As the operating temperature of the PEMFC is increased, the heat transfer rate increases as there is a larger temperature gradient between the fuel cell and the external environment. For an LT-PEMFC system, the heat removal using existing radiator technology found in transport vehicles is often insufficient. As a result, specialised cooling technology is required, all of which adds to the Balance of Plant (BoP) costs associated with the PEMFC. Increasing the temperature of the PEMFC will allow for existing cooling architectures present in transport vehicles to be used thus increasing the weight and mass specific energy densities and the overall energy efficiency. The efficiency can be further increased when cogeneration [17] and on-board reforming [8,14] are considered.

When operating at lower temperature $\left(80^{\circ} \mathrm{C}\right.$ or less) under atmospheric pressure a dual phase water system is present in the fuel cell. This dual phase water system must be kept in tight control due to the stringent humidification requirements of the membrane, which makes water management difficult. Higher operating temperatures mean that water management is simplified significantly as there is only a single (gaseous) phase present. This means that the transport of water in the membrane, electrodes and diffusion layer is easier and flow field plate design can be greatly simplified [10,11,13]. Another effect of the higher temperatures is that the reactant and product gases are expected to have increased diffusion rates [9] and with no liquid water present to block the electrochemically active surface area thus allowing for more reactions to occur. Both the simplified heat and water management mean that much simpler flow field designs can be used which should help decrease the overall cost of the stack as machining plates should be cheaper.

\subsection{Alternative catalysts}

Due to the increased electrode kinetics at higher temperatures, it becomes possible to utilise alternative catalysts [12] at the electrodes, thus significantly reducing the cost of the PEMFC. For example, due to the higher temperatures, iron (Fe) may be used as a catalyst 
to facilitate the reactions [18]. Other work has been performed with the use of cobalt (Co) as a catalyst for the fuel cell [19].

\section{Disadvantages}

Many years have been devoted to optimising the low temperature technology and each component within the PEMFC. For example, GDE, MEA, gaskets, bipolar plates and the rest of the BoP have been optimised for operation up to $8 \mathrm{o}^{\circ} \mathrm{C}$; still, however many issues remain unresolved. When temperature exceeds $100{ }^{\circ} \mathrm{C}$ dehydration of conventional membranes, which require humidification to aid proton conductivity, is experienced. This yields large ohmic losses, lower operating cell voltages and power densities [20]. Acidebase HT membranes, for example phosphoric acid doped PBI type materials, are thought to be a way of addressing dehydration issues; however, acid leaching from these materials leads to serious degradation of the fuel cell components. This in turn affects the power density and the performance/efficiency of the fuel cell. The other concern which could affect commercial viability is the increased start-up time (up to $40 \mathrm{~min}$ in some cases). The high temperature fuel cell must slowly be brought up to its operating temperature which could mean waiting for half an hour after start-up before any current can be drawn. As the average driving range is only around 23 miles per day in the UK (based on 2009 data), this would rule out HT-PEMFC use for any short distance driving [21].

\section{Progress towards high temperature operations 4.1 Membranes \\ 4.1.1 Targets}

The main objectives for all researchers in the development of novel membrane materials are to increase the performance and durability and to reduce the overall cost of fuel cells [22]. Table 1 lists the 2015 US DOE targets for HT-PEM materials. The targets incorporate the most important characteristics for PEMs, i.e. high conductivity, good thermal, mechanical and chemical stability, acceptable durability, compatibility with other fuel cell components, materials that are easy to work with and that can be recycled in an environmentally friendly manner $[2,23,24]$.

Although the DoE target temperature is $120^{\circ} \mathrm{C}$, many researchers are aiming for temperatures up to $200{ }^{\circ} \mathrm{C}$ as increased temperature leads to increased $\mathrm{CO}$ tolerance of the electrocatalyst [13]. CO tolerance is understood to mean operation in the presence of CO with voltage loss at the hydrogen electrode of less than $10 e 20 \mathrm{mV}$ [13]. CO tolerance is related to the thermodynamics of competitive $\mathrm{CO}$ and $\mathrm{H}_{2}$ adsorption (and fractional coverage, q) on the platinum surface of the catalyst. Fig. 2 shows the fractional coverage for different concentrations of $\mathrm{CO}$ at varying temperature. It has been shown that qCO should be below 0.9 for tolerance. The dissociative adsorption of $\mathrm{H}_{2}$ becomes more thermodynamically beneficial at higher temperatures than the associative adsorption of $\mathrm{CO}$ so at higher temperatures enough hydrogen is adsorbing on platinum sites for adequate hydrogen reduction. 
A 2005 cost analysis [27] of an 8o kW HT-PEMFC system projected a cost of $56 \mathrm{US} \$ / \mathrm{kW}$ for the MEA, assuming production of 500,000 units which represents $83 \%$ of the cost of the stack. In 2009 the actual cost of a fuel cell stack and balance of plant was $61 \mathrm{US} \$ / \mathrm{kW}$ [28], still short of the 30 US $\$ / \mathrm{kW}$ DoE target but it can be seen from Fig. 3 that the cost from initial estimated costs in 2002 are continually dropping.

Table 1

Targets for proton exchange membranes for transport application $[25,26]$.

\begin{tabular}{ll}
\hline Characteristic & 2015 Target \\
\hline Maximum operating temperature & $120^{\circ} \mathrm{C}$ \\
Unassisted start up from temperature & $-40^{\circ} \mathrm{C}$ \\
Conductivity & $0.1 \mathrm{~S} \mathrm{~cm}^{-1}\left(120^{\circ} \mathrm{C}\right)$ \\
& $0.07 \mathrm{~S} \mathrm{~cm}-1$ (Ambient temperature $)$ \\
& $0.01 \mathrm{~S} \mathrm{~cm}^{-1}\left(-20^{\circ} \mathrm{C}\right)$ \\
Area specific resistance & $0.02 \Omega \mathrm{cm}^{2}$ \\
Relative humidity/inlet water & $50 \% / 1.5 \mathrm{kPa}$ \\
$\quad$ vapour partial pressure & \\
Hydrogen/oxygen crossover at $1 \mathrm{~atm}$ & $2 \mathrm{~mA} \mathrm{~cm}$ \\
Cost & $20 \mathrm{US \$} / \mathrm{m}^{2}$ \\
Durability with cycling & $5000 \mathrm{~h}$ \\
\hline
\end{tabular}

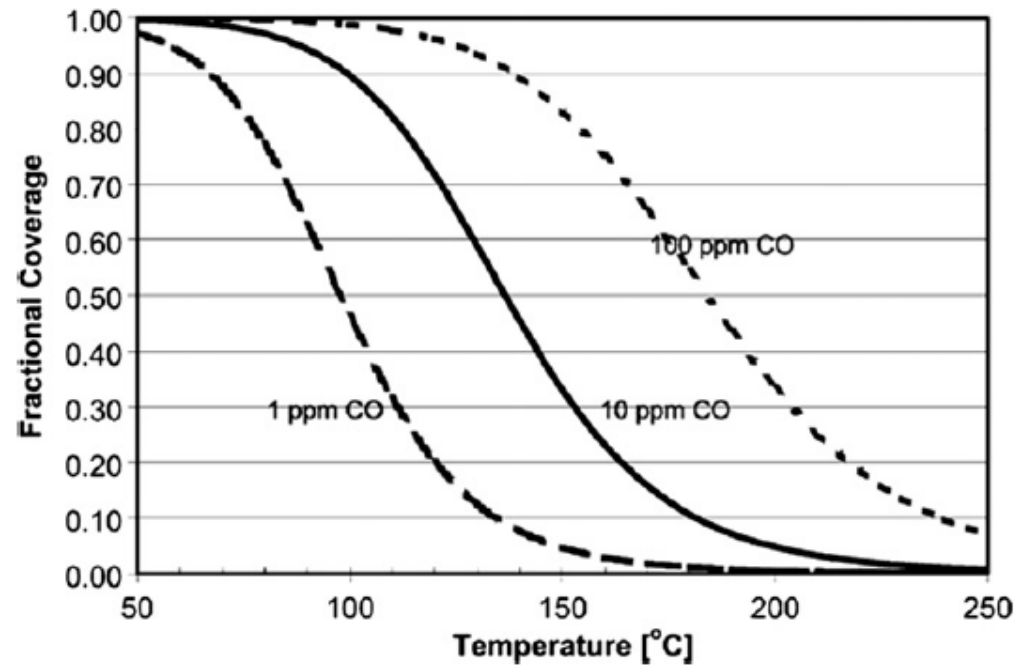

Fig. 2. CO coverage on a platinum surface at a hydrogen pressure of 0.5 bar. Different concentrations of $\mathrm{CO}$ is shown [13]. 


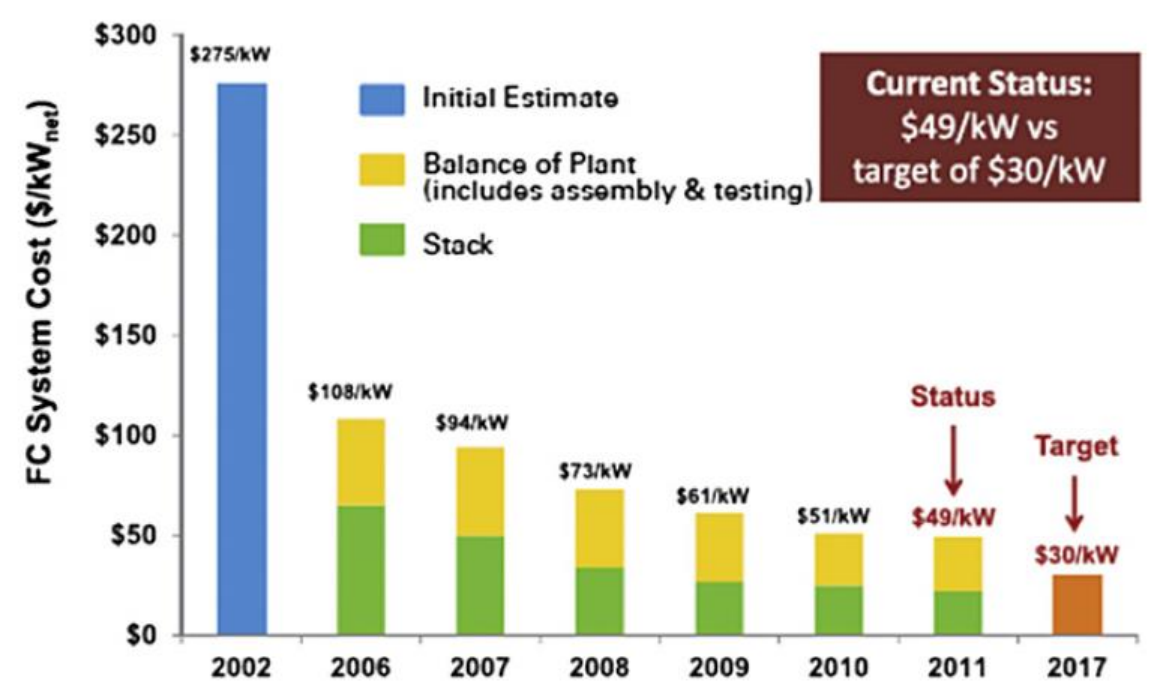

Fig. 3. Projected transportation fuel cell system cost, based on an $80 \mathrm{~kW}$ system and 500,000 production units per year [29].

The following section will briefly introduce Polymer Electrolyte Membrane and discuss recent advances in this field.

\subsubsection{Polymer Electrolyte Membrane (PEM)}

There have been many comprehensive reviews on PEMs [1,2,14,20,24,25,30e47]. The PEM can be considered in two parts. Firstly, the polymeric membrane material, including the backbone, the side chains and any fillers or support materials that have been added to enhance the material desirable properties. Secondly, the proton carrier, which is either water or an ionic medium such as phosphoric acid $\left(\mathrm{H}_{3} \mathrm{PO}_{4}\right)$ or an ionic liquid such as 1-butyl-3-methylimidazolium tetrafluoroborate $\left(\mathrm{BuMeImBF}_{4}\right)$ [48].

For all types of proton carriers there are similar considerations. Firstly, the membrane material must absorb an optimum amount of this medium; too much weakens the membrane, too little results in inadequate proton conductivity. Secondly, the membrane material must retain the maximum amount of the medium under operating conditions over a long period of time ( $5000 \mathrm{~h}$ for transport use, $40,000 \mathrm{~h}$ for stationary use). The loss of the conducting medium results in the reduction of conductivity, degradation of the membrane, damage or flooding of the electrodes and blockage of flow field plate (FFP) channels.

Conductivity takes place via diffusion or proton hopping. The mechanism that takes place depends upon which proton conducting medium is present. Fig. 4 illustrates the different mechanisms for water, phosphoric acid and an ionic liquid (1-butyl-3methylimidazolium bis (trifluoromethyl sulfonyl) imide).

Water containing membranes include Nafion ${ }^{\circledR}$, other fluorinated membranes and a large class of sulfonated aromatic hydrocarbons. The non-water membranes include 
acidebase systems such as polybenzimidazole (PBI) doped with phosphoric acid and materials rendered conductive by ionic liquids. To increase the uptake of the proton carrier, the concentration of the polar group (acid or base) on the polymer backbone must be maximised. In Table 2 the chemical structure for some of the most common base polymers used for PEM materials are shown.

Nafion ${ }^{\circledR}$ is usually obtained commercially as a film or as a 5 or $10 \mathrm{wt} \%$ solution in water and alcohol. Nafion ${ }^{\circledR}$ is synthesised by reacting tetrafluoroethylene (TFE) with sulfonic acid to form a sultone. The sultone is converted into an acid fluoride with a sulfonyl fluoride end group which is then reacted with hexafluoropropylene oxide and pyrolysed to form sulfonyl fluoride perfluorovinyl ether. Copolymerisation of this product with TFE in a perfluorinated solvent leads to a fluorinated precursor $\left(\mathrm{SO}_{3} \mathrm{~F}\right)$ which can be neutralised to the salt form $\left(\mathrm{SO}_{3} \mathrm{Na}\right)$ or hydrolysed to the acid form $\left(\mathrm{SO}_{3} \mathrm{H}\right)$ [52]. The alternatives to Nafion ${ }^{\circledR}$

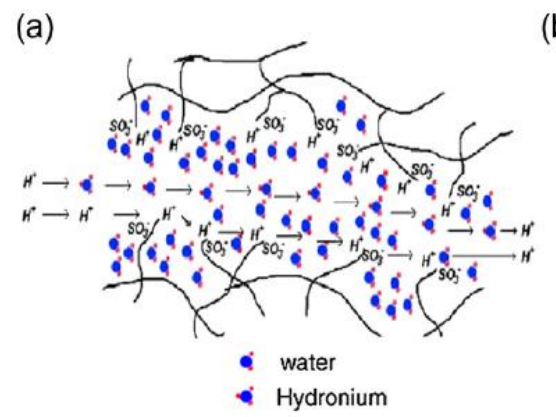

(b) (a)
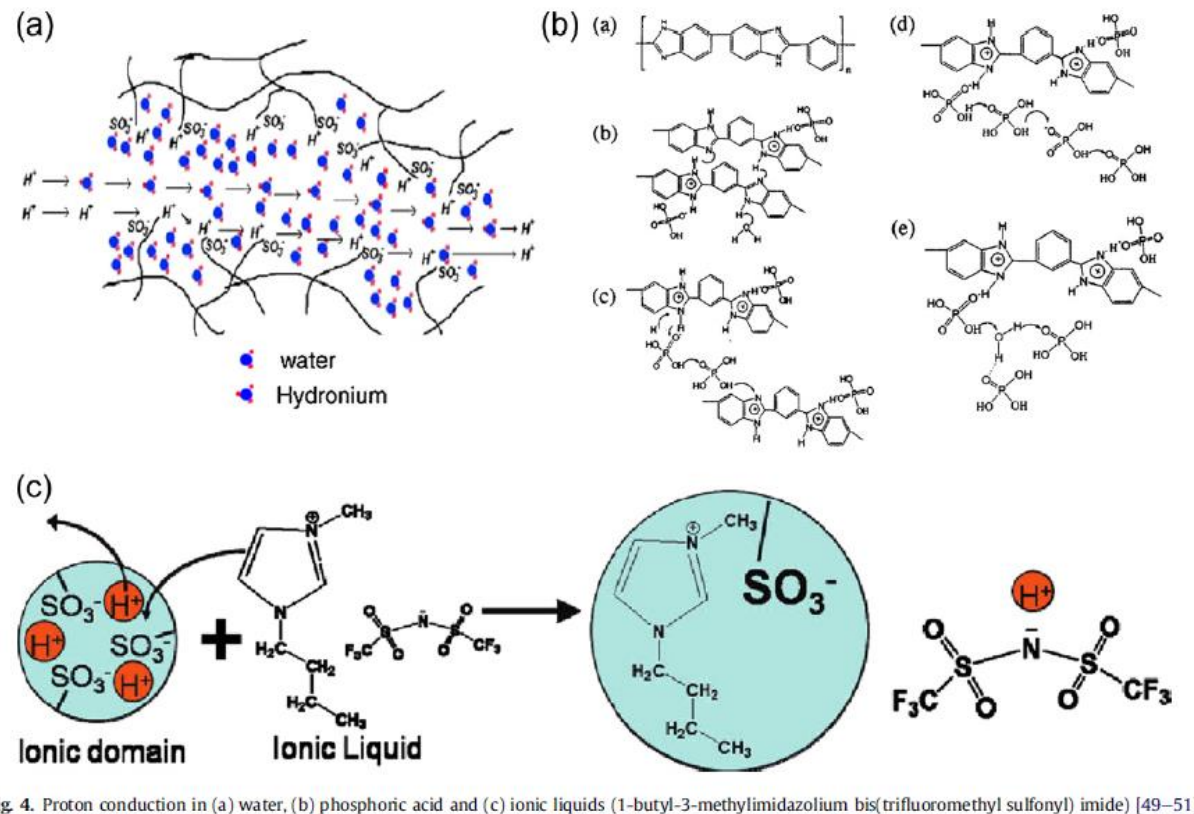

Fig 4. Proton conduction in (a) water, (b) phosphoric acid and (c) ionic liquids (1-butyl-3-methylimidazolium bis(trifluoromethyl sulfonyl) imide) [49-51] 


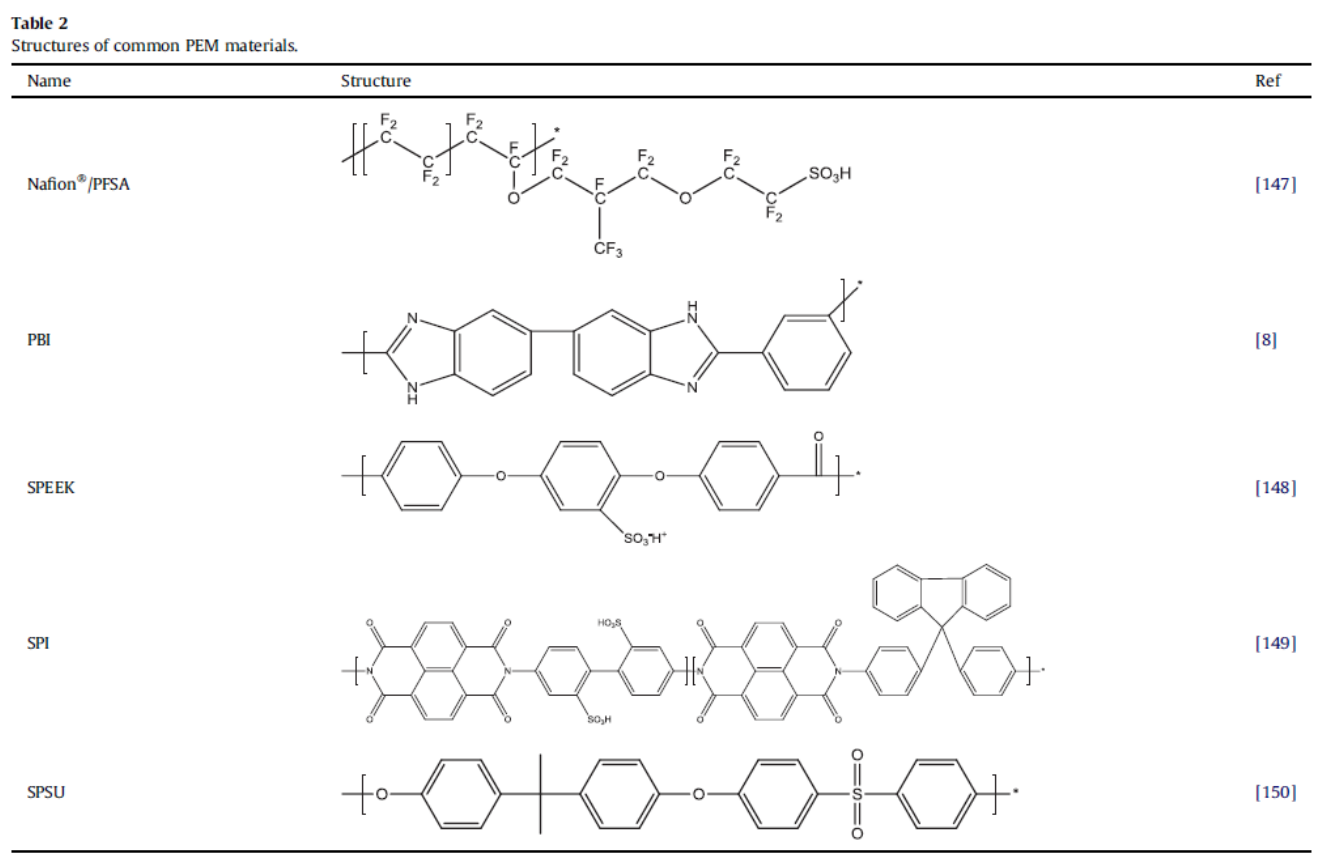

- The first obvious alternative to Nafion ${ }^{\circledR}$ is a perfluorinated sulfonic acid (PFSA) membrane which has been optimised for high temperature fuel cell application. Various short side chain (SSC) PFSAs have been developed over the years and notably, Stassi et al. [53] recently obtained good single cell performance with an Aquivion (Solvay Solexis) membrane at $130 \mathrm{O} \mathrm{C}$ and $100 \% \mathrm{RH}$ obtaining a power output of $870 \mathrm{~mW} \mathrm{~cm}^{-2}$ compared to $620 \mathrm{~mW} \mathrm{~cm}^{-2}$ for Nafion ${ }^{\circledR} \mathrm{N} 112$ under the same experimental conditions. Similar good performance was observed by Arico et al. [54] for Aquivion in small stack testing. Good single cell performance at reduced relative humidity was also observed by $\mathrm{Tu}$ et al. [55] with a composite SSC ionomer achieving $488 \mathrm{~mW} \mathrm{~cm}^{-2}$ at $95 \mathrm{O} \mathrm{C}$ and $40 \% \mathrm{RH}$. Performance deteriorated slightly in a $5 \mathrm{kV}$ stack and improvements in the assembly process are required. The improved performance of the SSC PFSA over the long side chain PFSA (like Nafion ${ }^{\circledR}$ ) is attributed to increased crystallinity and higher glass transition temperature of the polymer. Increased mechanical strength makes lower EW membranes possible which in turn results in increased IEC and proton charge carrier concentration [56].

- Polybenzimidazole (PBI) can be prepared by polymerisation of an appropriate diamine and carboxylic acid in polyphosphoric acid at $180 e 200{ }^{\circ} \mathrm{C}$ and the alternative form, ABPBI, is synthesised by the polymerisation of the diamine 3,4diamonobenzoic acid under similar conditions. Conductivity for ABPBI has been reported as $0.08 \mathrm{~S} \mathrm{~cm}^{-1}$ at $140^{\circ} \mathrm{C}$ with no hydration and $0.2 \mathrm{~S} \mathrm{~cm}^{-1}$ at $20 \% \mathrm{RH}$ [57]. Extensive reviews of these materials have recently been published by Assensio et al. [8] and Li et al. [58]. Recently, Lin et al. [59] reported increased mechanical strength and single cell performance for an epoxy (diglycidyl ether bisphenol-A) crosslinked PBI achieving a maximum power density of $172 \mathrm{~mW} \mathrm{~cm}^{-2}$ at $160^{\circ} \mathrm{C}$ 
and $0 \% \mathrm{RH}$ (at around $0.25 \mathrm{~V}$ ). Increased mechanical strength by using an epoxy cross-linker has been confirmed by Wang et al. [60] using 1,3-bis(2,3epoxypropoxy)-2,2-dimethylpropane and by Han et al. [61] using 4,40-diglycidyl (3,30,5,50-tetramethylbiphenyl) epoxy resin and in both cases proton conductivity levels were retained. Kim et al. [62] measured proton conductivity of $0.12 \mathrm{~S} \mathrm{~cm}^{-}$ 1 at $150^{\circ} \mathrm{C}$ at $\mathrm{O} \% \mathrm{RH}$ for a benzoxazine cross-linked PBI membrane and Aili et al. [63] obtained in-plane proton conductivity of $0.14 \mathrm{~S} \mathrm{~cm}^{-1}$ at $150{ }^{\circ} \mathrm{C}$ and $20 \% \mathrm{RH}$ for a PBI crosslinked with divinylsulfone. A new type of sulfonated PBI prepared by random copolymerisation of disodium 4,6-bis (4-carboxyphenoxy) benzene-1,3disulfonate, 4,4_-dicarboxydiphenyl ether and 3,3_-diaminobenzidine was recently reported with relatively high conductivity of $0.037 \mathrm{~S} \mathrm{~cm}^{-1}$ at $17 \mathrm{O}^{\circ} \mathrm{C}$ and $\mathrm{o} \% \mathrm{RH}$ (and promising single cell performance of around $300 \mathrm{~mW} \mathrm{~cm}^{-2}$ ) [64] and impressive conductivity of $0.376 \mathrm{~S} \mathrm{~cm}^{-1} 180{ }^{\circ} \mathrm{C}$ and $\mathrm{o} \% \mathrm{RH}$ was reported by Mader and Benicewicz [65,66] for a block copolymer consisting of sulfonated and non-sulfonated PBI segments.

- Sulfonated hydrocarbon polymers form another class of membranes which are suitable for higher temperature PEM fuel cells. Park et al. [46] recently compiled a detailed and extensive review of sulfonated hydrocarbon membranes for intermediate temperature application. The starting material for SPEEK is often commercial PEEK (Victrex or Fumatech) which is then sulfonated with concentrated sulphuric acid. A higher degree of control over the sulfonation level in the membrane chieved by the synthesis of a functionalised monomer such as reported by Krishnan et al. [67]. A monomer with a sulfonyl propoxy side chain was prepared and then polymerised with bisphenol-A and 4,4 $\mathrm{O}_{-}$ difluorobenzophenone but precipitation of the oligomers prevented the preparation of a high molecular weight polymer. Sulfonated polyimine (SPI) can be prepared by reacting a sulfonated diamine monomer, triethylamine, naphthalenetetracarboxylic dianhydride, a hydrophobic diamine monomer, benzoic acid and m-creosol at temperatures from $150^{\circ} \mathrm{C}$ to $195^{\circ} \mathrm{C}$ [68]. In the same fashion as SPEEK, sulfonated polysulfone (SPSU) can be prepared by the sulfonation of commercial PSU with chlorosulfonic acid [69] or by the polymerisation of sulfonated and unsulfonated monomers [70].

- Composite membranes are attracting a great deal of attention as a means for increasing the temperature tolerance of conventional PEM materials. They are manufactured by doping a polymer with a filler material and was recently classified by Dupuis [30]. The main objective of adding a filler is to improve water uptake and retention [71,72] and by implication the conductivity at high temperature and low humidification. Most types of polymer electrolytes have successfully been doped with inorganic fillers such as hygroscopic oxides $\left(\mathrm{SiO}_{2}\right.$, $\mathrm{TiO}_{2}, \mathrm{ZrO}_{2}, \mathrm{Al}_{2} \mathrm{O}_{3}$ ), clays (montmorillonite), zeolites, mineral acids ( $\mathrm{HCl}$, $\mathrm{H}_{3} \mathrm{PO}_{4}$ ), heteropoly acids and zirconium phosphates ( $\left.\mathrm{ZrP}\right)$. Recent success has also been reported with pure and functionalised graphene oxide (GO) and with 
polymeric micro or nano capsules. Table 3 lists a selection of materials reported in recent literature.

- Inorganic or solid acid membranes is another promising class of membranes for higher temperature fuel cells. This class of materials undergo a superprotonic phase transition; when passing through a specific temperature, their proton conductivity increases by several orders of magnitude. An extensive review of the materials is provided by Dupuis [30] categorising the materials in three classes; $\mathrm{MHXO}_{4}, \mathrm{MH}_{2} \mathrm{XO}_{4}, \mathrm{M}_{3} \mathrm{H}\left(\mathrm{XO}_{4}\right)_{2}$ (with $\mathrm{M} 1 / 4 \mathrm{~K}, \mathrm{Rb}, \mathrm{Cs}, \mathrm{Tl}, \mathrm{Li}$, or $\mathrm{NH}_{4}$ and $\mathrm{X} 1 / 4 \mathrm{P}, \mathrm{S}$, As or Se). The most promising material appears to be $\mathrm{CsHSO}_{4}$ with a superprotonic temperature of $140 \mathrm{O}$ C. As early as 2001 this class of membranes was reported in Nature [73] when it was first tested in a fuel cell at $150 e 160 \mathrm{O} C$ and more recent studies showed conductivity of $0.04 \mathrm{~S} \mathrm{~cm}^{-1}$ at $200 \mathrm{OC}^{\mathrm{C}}$ [13], and blending with microporous zeolite improved conductivity [74]. However, the published single cell performance for these materials is poor. Other groups have investigated the use of ferroxane [75] obtaining proton conductivity in the region of $10^{-2} \mathrm{~S} \mathrm{~cm}^{-1}$ at room temperature. These materials offer a promising alternative to polymer membranes but challenges of water solubility, mechanical instability and compatibility with other cell components need to be addressed.

Preparation methods (Table 4) are crucial to the membrane properties. This includes choice of solvent, extrusion versus casting and thermal post-treatment $[56,76]$. When inorganic additives are used, the preparation of the additive as well as the composite membrane materials are crucial to the performance of the materials [71]. 
Table 3

Examples of composite PEMs.

\begin{tabular}{|c|c|c|}
\hline Class & PEM example & Ref \\
\hline $\begin{array}{l}\text { Hygroscopic } \\
\text { oxides }\end{array}$ & $\begin{array}{l}\text { Nafion }{ }^{\oplus} \text { doped with } \mathrm{TiO}_{2} \text { increases } \\
\text { water uptake, } \mathrm{HT} \text { conductivity and } \\
\text { mechanical durability. }\end{array}$ & {$[151,152]$} \\
\hline Clays & $\begin{array}{l}\text { Sulfonated polysulfone/PTFE membrane doped } \\
\text { with sulfonated montmorillonite showed good } \\
\text { water retention and mechanical strength. }\end{array}$ & [153] \\
\hline Zeolites & $\begin{array}{l}\text { PVDF doped with ETS- } 10 \text { ( } \mathrm{SiO}_{4} \text { tetrahedra and } \\
\mathrm{TiO}_{6} \text { octahedra) has increased conductivity up } \\
\text { to } 150{ }^{\circ} \mathrm{C} \text {. }\end{array}$ & [154] \\
\hline Mineral acids & $\begin{array}{l}\text { Both PFSA and PBI are successfully doped with } \\
\mathrm{H}_{3} \mathrm{PO}_{4} \text { resulting in increased conductivity under } \\
\text { dry conditions. }\end{array}$ & [30] \\
\hline Solid acids & $\begin{array}{l}\text { A Nafion }{ }^{\oplus} / \mathrm{Cs}_{2.5} \mathrm{H}_{0.5} \mathrm{PW}_{12} \mathrm{O}_{40} \text { composite shows } \\
\text { increased water uptake and proton conductivity. }\end{array}$ & [155] \\
\hline $\begin{array}{l}\text { Heteropoly } \\
\text { acids (HPAs) }\end{array}$ & $\begin{array}{l}\text { SPEEK with zirconium oxide and } \\
\text { phosphomolybdic acid shows high proton } \\
\text { conductivity and increased } \\
\text { thermal stability. }\end{array}$ & [156] \\
\hline $\begin{array}{l}\text { Zirconium } \\
\text { phosphates }\end{array}$ & $\begin{array}{l}\text { SPEEK, PTFE and Nafion }{ }^{\circledast} \text { doped with } \mathrm{ZrP} \text { showed } \\
\text { increased conductivity at low humidification and } \\
\text { enhanced chemical stability. }\end{array}$ & [157] \\
\hline Graphene oxide & $\begin{array}{l}\text { Nafion }{ }^{\circ} \text { doped with sulfonic acid functionalised } \\
\text { graphene oxide showed increased conductivity } \\
\text { at } 120^{\circ} \mathrm{C} \text { and } 30 \% \mathrm{RH} \text {. }\end{array}$ & [79] \\
\hline $\begin{array}{l}\text { Polymeric } \\
\text { capsules }\end{array}$ & $\begin{array}{l}\text { Nafion }{ }^{\circ} \text { doped with sulfonated polystyrene } \\
\text { nanospheres showed increased conductivity } \\
\text { above } 100{ }^{\circ} \mathrm{C} \text {. }\end{array}$ & [158] \\
\hline
\end{tabular}


Table 4

Effect of preparation methods.

\begin{tabular}{|c|c|c|}
\hline Method & Effect & Ref \\
\hline Solvent & $\begin{array}{l}\text { SPEEK membranes cast from solvent } \\
\text { performed better in the order } \\
\text { NMP }>\text { DMSO }>\text { DMAC }>\text { DMF. Solvents } \\
\text { affect polymer nanostructure and have } \\
\text { different interactions with the acid } \\
\text { group on the SPEEK backbone. }\end{array}$ & $\overline{[76,159]}$ \\
\hline $\begin{array}{l}\text { Extrusion and } \\
\text { solution casting }\end{array}$ & $\begin{array}{l}\text { Extrusion leads to orientated polymer } \\
\text { chains and anisotropic water swelling. } \\
\text { Solution cast membranes swell } \\
\text { isotropically. }\end{array}$ & {$[160]$} \\
\hline Electrospun fibres & $\begin{array}{l}\text { Electrospun sulfonated poly (fluorenyl } \\
\text { ether ketone) fibres result in higher } \\
\text { chemical stability and improved single } \\
\text { cell performance compared to cast } \\
\text { membranes. }\end{array}$ & {$[161]$} \\
\hline Activation/purification & $\begin{array}{l}\text { A wide range of procedures are } \\
\text { reported. Typically solvent is } \\
\text { evaporated at elevated temperature, } \\
\text { membranes are successively boiled in } \\
\mathrm{H}_{2} \mathrm{O}_{2} \text {, deionised water and } \mathrm{SO}_{3} \mathrm{H}_{2} \text { and } \\
\text { finally annealed at high temperature. }\end{array}$ & \\
\hline $\begin{array}{l}\text { Polymer post } \\
\text { sulfonation vs direct } \\
\text { polymerisation } \\
\text { of sulfonated } \\
\text { monomers }\end{array}$ & $\begin{array}{l}\text { Post sulfonation can lead to polymer } \\
\text { chain degradation, undesirable side } \\
\text { reactions and unpredictable degree of } \\
\text { sulfonation. However few commercial } \\
\text { sulfonated monomers are available and } \\
\text { steric hindrance can lead to reduced } \\
\text { polymer molecular weight. }\end{array}$ & {$[46,162]$} \\
\hline Thermal treatment & $\begin{array}{l}\text { The thermal history affects the } \\
\text { properties of membranes and should be } \\
\text { constant for materials being compared } \\
\text { in a study. }\end{array}$ & {$[25,163]$} \\
\hline \multirow[t]{2}{*}{ Filler shape/type/loading } & $\begin{array}{l}\text { Zirconium phosphate ( } \mathrm{ZrP}) \text { nanosheets } \\
\text { increase conductivity more than } \mathrm{ZrP} \\
\text { particles due to larger filler/polymer } \\
\text { interface. }\end{array}$ & [157] \\
\hline & $\begin{array}{l}10 \text { wt\% graphene oxide (GO) in Nafion } \\
\text { led to higher ex-situ proton } \\
\text { conductivity than } 5 \text { wt\% }\end{array}$ & [79] \\
\hline \multirow[t]{3}{*}{$\begin{array}{l}\text { Pretreatment of } \\
\text { filler particles }\end{array}$} & $\begin{array}{l}\text { SiWA neutralised with } \mathrm{NaOH} \text { prior to } \\
\text { doping in PBI prevented agglomeration } \\
\text { and lead to well defined proton } \\
\text { pathways. }\end{array}$ & [78] \\
\hline & $\begin{array}{l}\mathrm{SiO}_{2} \text { nanoparticles grafted with } \\
\text { polyvinylimidazole (PVI) showed } \\
\text { higher conductivity and acid uptake } \\
\text { when doped in poly [2,2'-(m- } \\
\text { pyrazolidene)-5,5'-bibenzimidazole] } \\
\text { (PPBI) compared with as received } \mathrm{SiO}_{2} \\
\text { particles. }\end{array}$ & [164] \\
\hline & $\begin{array}{l}\text { Sulfonated polystyrene (SPS) } \\
\text { nanocapsule composite have higher } \\
\text { conductivity and unf unctionalised PS } \\
\text { composite. }\end{array}$ & {$[165]$} \\
\hline
\end{tabular}


Summary of potential high temperature membrane materials.

\begin{tabular}{|c|c|c|}
\hline Membrane material & Conductivity/Temp/\%RH & Ref \\
\hline 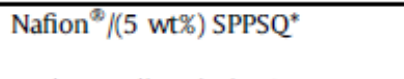 & $\begin{array}{l}0.157 \mathrm{~S} \mathrm{~cm}^{-1} \text { at } 120^{\circ} \mathrm{C} \text { and } 100 \\
\text { \% RH }\end{array}$ & $\overline{[166]}$ \\
\hline $\mathrm{PBI} / \mathrm{H}_{3} \mathrm{PO}_{4} /(40 \%) \mathrm{SiWA}$ & $\begin{array}{l}0.177 \mathrm{~S} \mathrm{~cm}^{-1} \text { at } 150{ }^{\circ} \mathrm{C} \text { and } 0 \\
\text { \% RH }\end{array}$ & [78] \\
\hline Recast Nafion ${ }^{\infty * *}$ & $\begin{array}{l}0.002 \mathrm{~S} \mathrm{~cm}^{-1} \text { at } 130{ }^{\circ} \mathrm{C} \text { and } 100 \\
\text { \% RH }\end{array}$ & [167] \\
\hline Nafion ${ }^{2} *$ & $\begin{array}{l}0.035 \mathrm{~S} \mathrm{~cm}^{-1} \text { at } 120^{\circ} \mathrm{C} \text { and } 30 \\
\text { \% RH }\end{array}$ & [168] \\
\hline Nafion ${ }^{\infty} 117 /(20 \mathrm{wt} \%) \mathrm{ZrSPP}$ & $0.1 \mathrm{~S} \mathrm{~cm}^{-1}$ at $100^{\circ} \mathrm{C}$ and $90 \% \mathrm{RH}$ & [169] \\
\hline Recast Nafion ${ }^{*} /(20$ wt\%) ZrSPP* & $\begin{array}{l}0.05 \mathrm{~S} \mathrm{~cm}^{-1} \text { at } 110^{\circ} \mathrm{C} \text { and } 98 \% \\
\mathrm{RH}\end{array}$ & [170] \\
\hline Recast Nafion ${ }^{*} /$ SGO & $\begin{array}{l}0.047 \mathrm{~S} \mathrm{~cm}^{-1} \text { at } 130^{\circ} \mathrm{C} \text { and } 30 \\
\text { \% RH }\end{array}$ & [168] \\
\hline SPEEK-WC & $\begin{array}{l}0.00022 \mathrm{~S} \mathrm{~cm}^{-1} \text { at } 96{ }^{\circ} \mathrm{C} \text { and } 85 \\
\text { \%RH }\end{array}$ & [171] \\
\hline SPEEK-WC/SiW (9.6 wt\%) & $\begin{array}{l}0.0013 \mathrm{~S} \mathrm{~cm}^{-1} \text { at } 96{ }^{\circ} \mathrm{C} \text { and } 85 \\
\text { \%RH }\end{array}$ & [171] \\
\hline SPEEK/poly(imi-alt-CTFE) & $\begin{array}{l}0.001-0.015 \mathrm{~S} \mathrm{~cm}^{-1} \text { at } 120^{\circ} \mathrm{C} \\
\text { and } 25-95 \% \mathrm{RH}\end{array}$ & [172] \\
\hline SPEEK/ZrP-NS) & $\begin{array}{l}0.079 \mathrm{~S} \mathrm{~cm}^{-1} \text { at } 150{ }^{\circ} \mathrm{C} \text { and } 100 \\
\text { \%RH }\end{array}$ & [157] \\
\hline SPI with fluorene groups & $\begin{array}{l}1.67 \mathrm{~S} \mathrm{~cm}^{-1} \text { at } 120^{\circ} \mathrm{C} \text { and } 100 \\
\text { \%RH }\end{array}$ & [149] \\
\hline SPI with fluorene groups & $\begin{array}{l}0.003 \mathrm{~S} \mathrm{~cm}^{-1} \text { at } 160{ }^{\circ} \mathrm{C} \text { and } 12 \\
\text { \% RH }\end{array}$ & [173] \\
\hline $\begin{array}{l}\text { SPI with sulfophenoxypropoxy } \\
\text { pendants }\end{array}$ & $1 \mathrm{~S} \mathrm{~cm}^{-1}$ at $120^{\circ} \mathrm{C}$ at $100 \% \mathrm{RH}$ & [174] \\
\hline SPU with fluorene & $0.5 \mathrm{~S} \mathrm{~cm}^{-1}$ at $110^{\circ} \mathrm{C}$ and $50 \% \mathrm{RH}$ & [175] \\
\hline $\mathrm{CF}_{6}-\mathrm{PBI}$ & $\begin{array}{l}0.12 \mathrm{~S} \mathrm{~cm}^{-1} \text { at } 175^{\circ} \mathrm{C} \text { and } 10 \\
\text { \% } \mathrm{RH}\end{array}$ & [109] \\
\hline $\mathrm{SO}_{2}-\mathrm{PBI}$ & $0.12 \mathrm{~S} \mathrm{~cm}^{-1}$ at $180^{\circ} \mathrm{C}$ and $5 \% \mathrm{RH}$ & [176] \\
\hline PBI/SPAES & $\begin{array}{l}0.045 \mathrm{~S} \mathrm{~cm}^{-1} \text { at } 200^{\circ} \mathrm{C} \text { no } \\
\text { external humidification }\end{array}$ & [177] \\
\hline $\begin{array}{l}\text { PSU with pyridine and } \\
\text { hydroquinone groups }\end{array}$ & $0.02 \mathrm{~S} \mathrm{~cm}^{-1}$ at $120^{\circ} \mathrm{C} 0 \% \mathrm{RH}$ & [23] \\
\hline $\begin{array}{l}\text { 72TEOS-18PDMS }-10 \mathrm{PO} \\
\left(\mathrm{OCH}_{3}\right)_{3} / 40 \%[\mathrm{EMI}][\mathrm{TFSI}]\end{array}$ & $0.00487 \mathrm{~S} \mathrm{~cm}^{-1} 150{ }^{\circ} \mathrm{C} 0 \% \mathrm{RH}$ & [178] \\
\hline $\begin{array}{l}\text { TMOS-TMPS-TEP/(40\%) } \\
\text { BMIMBF }_{4}\end{array}$ & $0.006 \mathrm{~S} \mathrm{~cm}^{-1} 150{ }^{\circ} \mathrm{C} 0 \% \mathrm{RH}$ & [179] \\
\hline $\begin{array}{l}\text { 30TMOS-30TEOS-30MTEOS } \\
-10 \mathrm{PO}\left(\mathrm{OCH}_{3}\right)_{3} /(40 \%) \\
\text { EMIMBF }_{4}\end{array}$ & $0.01 \mathrm{~S} \mathrm{~cm}^{-1} 155^{\circ} \mathrm{C} 0 \% \mathrm{RH}$ & [180] \\
\hline $\begin{array}{l}\text { 60TMOS-30VTMOS } \\
-10 \mathrm{PO}\left(\mathrm{OCH}_{3}\right)_{3} /(40 \%) \\
\text { EMIMBF }_{4}\end{array}$ & $0.0089 \mathrm{~S} \mathrm{~cm}^{-1} 155^{\circ} \mathrm{C} 0 \% \mathrm{RH}$ & [180] \\
\hline
\end{tabular}

*Membrane cast from 5 wt $\%$ Nafion ${ }^{\star} 1100$ solution, DuPont. ${ }^{* *}$ Membrane cast from Nafion ${ }^{\star}$ resin, Shandong Dongyue Polymer Material Co. Ltd.

Table 5 summarises data on promising high temperature membrane materials and the entries that are highlighted have met DoE targets for 2015.

It is clear that various materials exist which satisfy either high temperature or low humidity requirements, but that fewer exist that satisfy both requirements at the same time. Anhydrous materials such as polybenzimidazole show the best potential for high temperature application and hydrated materials, such as polysulfones and polyimides would be best suited for intermediate application. 
Both temperature ranges show benefits and drawbacks. The anhydrous materials like PBI offer high current densities at high temperature (Fig. 5) but concerns remain regarding low temperature operation, acid leaching and the long start-up time. Recently however, an innovative method of imbibing the conductive phosphoric acid via the electrodes and gas diffusion layers (rather than doping the PBI membrane) has shown promising fast start-up results. Wannek et al. [57,77] reported a power density of $120 \mathrm{~mW}$ at $600 \mathrm{mV}$ after only $11 \mathrm{~min}$ of operation for an ABPBI membrane.

The highly specialised new fluorinated and polyaromatic hydrocarbon materials show promising high temperature conductivity (Fig. 6) but the humidity requirement adds cost and complication to the balance of plant. This could be acceptable if the power output is significantly increased and if long term thermal, chemical and mechanical durability can be shown through in-situ testing.

\subsection{Catalysts}

Within the LT-PEMFC, one aspect that has received a lot of attention is the catalyst layer. This is potentially one of the biggest challenges for the widespread usage of PEMFC technology as currently the catalyst layer within the PEMFC contains platinum, a PGM (Platinum Group Metal). The DOE have set targets for the PGM loading in the stack for 2015 (see Table 6 [81]). The degradation of the platinum is common when the fuel cell is used for extended periods of time [82]. In PEMFC systems, the catalyst layer is a complex structure that consists of support material (carbon black) and an ionomer (Nafion ${ }^{\circledR}$ ) for proton conduction. This layer must be sufficiently porous for the removal of waste water and transport of the reactant gases.

One of the major issues with using platinum as a catalyst is its propensity to degrade. There are three main mechanisms that are widely accepted as being the methods of degradations: (i) the carbon supports corrode [83]; (ii) the platinum particles dissolve, leading to particle growth via Ostwald ripening, when the platinum is deposited [84]; (iii) the platinum particles agglomerate and sinter together on the carbon support via passive diffusion processes [85]. Novel methods for LT-PEMFC catalyst layer fabrication to increase active platinum surface area and thus decrease overall platinum levels are demonstrated by Curnick et al. [86]. 

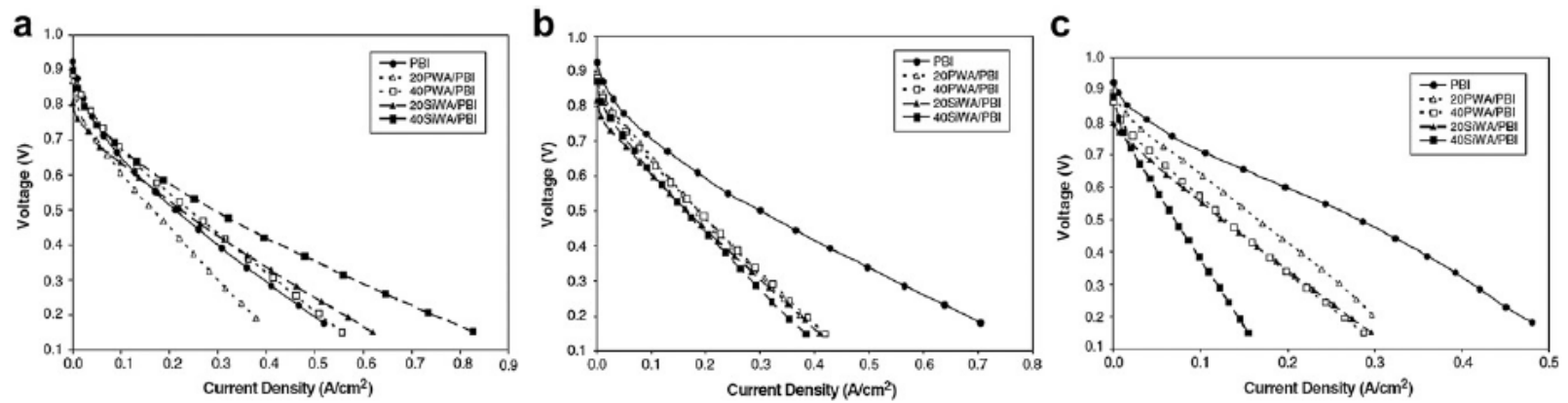

Fig. 5. Single cell conductivity of PBI doped with various loadings of silicotungstic acid. Temperatures (a) 120 , (b) 150 and (c) $180^{\circ} \mathrm{C}$ all with dry fuel gas [78].
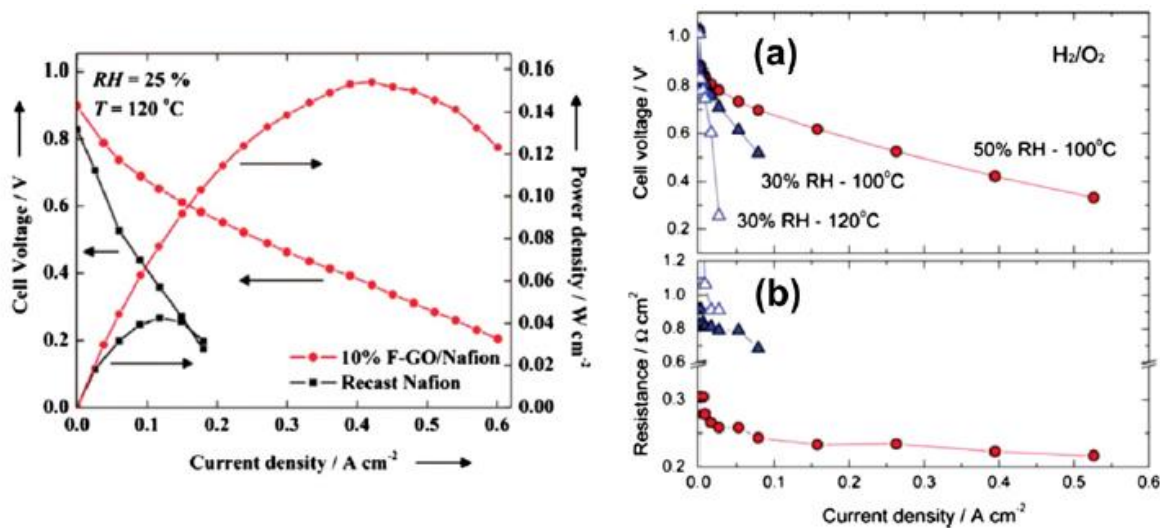

Fig. 6. Power curves showing the performance of Nafion ${ }^{\infty}-$ GO composite membrane (left) [79] and poly(arylene ether sulfone ketone) with optimised Nafion ${ }^{\infty}$ free MEA [79,80].

They found that, by using the ionomer (Nafion ${ }^{\circledR}$ ) as a surfactant, they were able to stabilise the platinum particles by both steric and electrostatic mechanism (see Fig. 7 [86]). They also found that they could achieve good interfacial contact between these two phases, which remained upon adding the carbon support. This was advantageous because it led to a highly effective distribution of Nafion ${ }^{\circledR}$ ionomer allowing for good contact between the platinum and the proton conducting network (allowing for $90 \%$ utilization of platinum) [86]. Further research would be required to see whether it is possible to utilise the same techniques using the high temperature PBI based membrane ionomers and to see if this will allow for such a high level of platinum utilisation.

It may also be possible to use alternative catalysts to platinum due to the increased reaction kinetics (due to the increased operating temperatures). There are other metals that are able to catalyse the ORR, for example iron and cobalt. Villers et al. [18] have demonstrated that the catalyst support material plays a large role in the catalytic activity. Interestingly, they found for an LT-PEMFC system, that the nitrogen content on the surface of the catalyst had a large effect on the catalytic activity of the iron. It is also possible to use platinum based binary electrocatalyst alloys such as $\mathrm{PtFe}, \mathrm{PtCo}, \mathrm{PtNi}, \mathrm{PtCr}$ and $\mathrm{Pt} / \mathrm{RuO}_{2} \mathrm{eSiO} x$ which exhibit much higher catalytic activity than pure Pt for the ORR reactions [87e89]. Recently, platinum based binary electrocatalyst were also tested for HT-PEMFC conditions, such as, 
$\mathrm{Pt} / \mathrm{SnO}_{x}$ [90] and PtCo [54]. It was found that the use of these catalyst layers enhance the stability and performance of the fuel cell at HT operating conditions.

\subsection{Gas diffusion layer and flow field plates}

The porous GDL plays an essential role to assist the reactions on the catalyst layer by diffusing the reactants from the flow channels to reach the active sites on the catalyst. It also enhances humidification in the membrane by allowing water vapour to diffuse along with the reactants. At the same time liquid water produced on the cathode can flow out of the cell to prevent water flooding and blocking of the active sites on the catalyst [42]. However, no liquid water is expected to be present when operating at temperatures over $100{ }^{\circ} \mathrm{C}$, therefore, the demand on GDL properties for water transport at high temperature is reduced. The GDL offers a supporting structure for the catalyst layer and links the catalyst particles electronically. It is an electrically conducting medium that transfers electrons between the catalyst layer and the bipolar plate [91]. State of the art GDL materials seem to be used for both low and high temperature PEMFCs. Table 7 shows some types of GDLs used in HT-PEMFCs in literature. To the authors knowledge, only one paper has been found in the literature on GDLs for high temperature, i.e., Lobato et al. [92] which studied the effect of PTFE loading in the GDL on PBI-based PEM fuel cell. It was reported that lower PTFE loading results in a higher cell performance but it has a negative effect on the mechanical properties of the GDL and a 10\% PTFE loading is suggested as an optimum value for HT PEM. Further work is required to optimize GDL properties for HTPEM fuel cells. The Flow Field Plate (FFP) supplies and distributes the reactants over the GDL, removes water, collects current, and provides mechanical support for the cell or stack. The DOE have set targets for 2015 for the FPP (see Table 8 [81]). Graphite plates have been traditionally used in fuel cells because of their chemical stability and high electrical conductivity, which makes them suitable for HT-PEMFC. Metallic plates are considered superior alternatives for graphite plates due to the reduction in cost, increased volumetric power density and higher mechanical strength [93]. The high temperature cell operation prevents the formation of liquid water in the cell, therefore, allows the use of a wider range of flow field designs without facing the water management problem. The effect of flow field designs for HT-PEM has been studied both experimentally [7] and by modelling [94,95]. These studies show the significant effect of flow field design on the performance, and focuses on the pressure and current distribution over the surface of the cell. There are different configurations of flow channel, all of which are machined onto the FFP plates. These various configurations have been studied in an attempt to find an optimum design for fuel cell operation. Parallel [15,96], single serpentine [97e103], multiple serpentine [104], etc. are the most common designs used in PEMFC.

Temperature increase enhances the degradation process and puts higher demand on the material stability. Recently, Hartnig et al. [105] studied the effect of bipolar plate degradation in a high temperature acid based fuel cell on the overall performance; the study shows a significant effect of the material surface morphology and hydrophobicity on the degradation. Porous and hydrophilic surfaces increase the plate acid uptake contributing 
to the MEA performance loss. The study shows stable densely coated materials, such as gold coated plates and surface treated graphite, have higher tolerance and lower degradation rates.

Table $\mathbf{6}$
\begin{tabular}{llll} 
US DOE targets for PGM loading in the stack. \\
\hline Characteristics & Units & \multicolumn{2}{l}{ Stack targets } \\
\cline { 3 - 4 } & & 2010 & 2015 \\
\hline $\begin{array}{c}\text { PGM total content } \\
\text { (both electrode) }\end{array}$ & $\mathrm{g} / \mathrm{kW}$ (rated) & 0.3 & 0.2 \\
PGM total loading & $\mathrm{mg} \mathrm{PGM} / \mathrm{cm}^{-2}$ electrode area & 0.3 & 0.2 \\
\hline
\end{tabular}
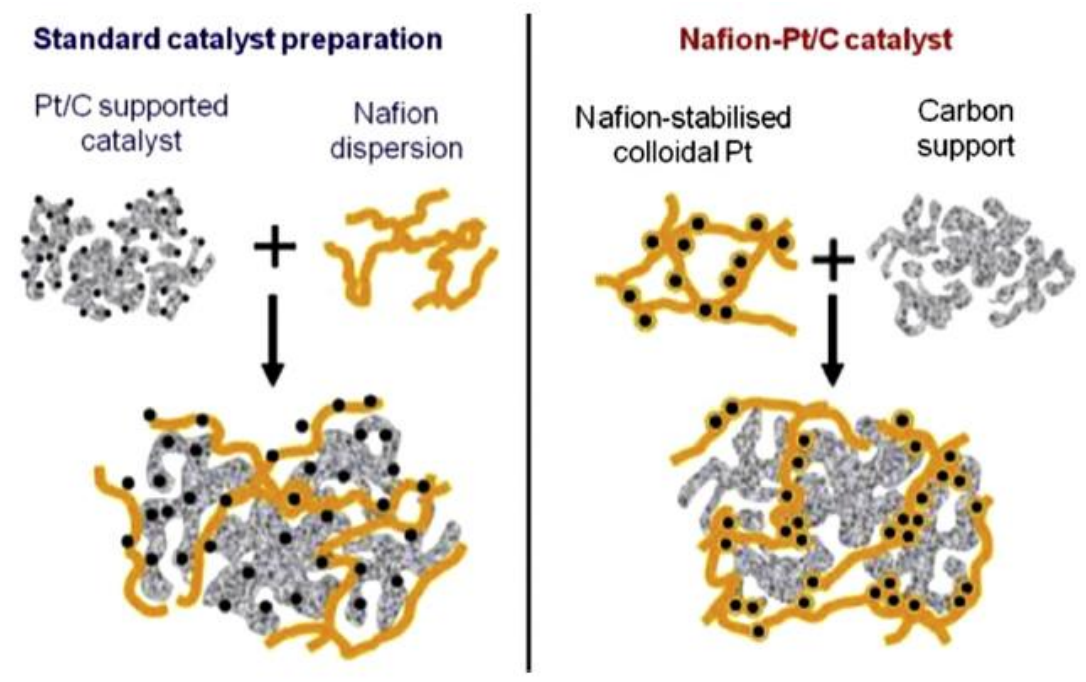

Fig. 7. Schematic illustration of catalyst layer morphology \& TEM micrographs for (a) Nafion ${ }^{\star}$ - derived Pt/C catalyst and (b) E-Tek commercial $20 \mathrm{wt} \% \mathrm{Pt} / \mathrm{C}$ [86].

\subsection{MEA manufacture}

The preparation of the MEA involves four steps. Firstly, the GDL material must be selected or prepared. The second step includes selecting or preparing the catalyst support material [106], the catalyst itself, the solvent and the ionomer which are all used together to prepare the catalyst ink. The third step involves the catalyst ink deposition, either on the membrane (the so-called Catalyst Coated Membrane method (CCM)) directly or on the GDL (Catalyst Coated Substrate (CCS)). The final step is the hot-pressing of the electrodes onto the membrane although this step is not required for the CCM method. A few examples of the preparation methods are set out in Table 9.

There are several methods of fabricating the electrodes that are used in the production of the MEA. The oldest method is known as the PTFE-bound method. This involves a slurry that contains the PTFE (Teflon) and electrocatalyst/support [107] which is deposited onto the GDL. This layer would then be impregnated with the Nafion ${ }^{\circledR}$ ionomer. This method results in low platinum utilisation (approximately 20\%) as there is poor contact between the Pt nanoparticles and the Nafion ${ }^{\circledR}$ ionomer, which ultimately lead to the development of the thin film method. The thin film method is commonly used in the fabrication of the catalyst 
layer. This method involves an electrocatalyst slurry (solvent, ionomer \& electrocatalyst/support powder) that is used to coat either the GDL (CCS) or the membrane (CCM) [108]. It has been shown that this method decreases interfacial resistance and increased platinum utilization by providing good contact between the catalyst particles and the ionomer allowing for a higher Triple Phase Boundary (TPB).

Other methods include electrodeposition, sputtering, dual ionbeam deposition and physical deposition. It can be seen from Table 9 that preparation methods vary to a great extent between research groups. This results from the requirement for optimisation for each system. Comparison of single cell data from different studies should therefore be undertaken with caution as explained by Li et al. [109] whilst comparing the single cell data for various PBI materials (Fig. 8).

Among the reasons for high temperature operations, one of the most important is being able to fabricate MEAs with much lower catalyst loadings. Novillo et al. [110] conducted studies on the platinum levels required for high temperature operation. They deposited platinum using DC magnetron sputtering from a platinum target (99\%). As expected, it was found that when the sputtering time was increased, agglomeration of the platinum particles was found to occur. However using careful control of the sputtering lead to nano-sized platinum particles. When characterisation on the catalyst layer was performed, it was found that at these lower loadings (0.035 $\mathrm{mg} \mathrm{cm}^{-2}$ compared to the $0.35 \mathrm{mg} \mathrm{cm}^{-2}$ in an LT-PEMFC catalyst layer) the electrochemical performance was very similar (a difference of $50 \mathrm{mV}$ at current densities below $800 \mathrm{~mA} \mathrm{~cm}^{-2}$ ) [110] which shows great promise for future applications. Although the sputtering can give these low platinum loadings, there are issues with the Pt utilisation including the poor adherence of the Pt to the substrate surface, which ultimately leads to a shorter lifetime.

At higher operating temperature, the interfacial resistance is expected to increase due to increased degradation of the membrane if conventional humidified materials are used.

$\begin{aligned} & \text { Table } 7 \\
& \text { Examples of GDLs reported in the literature. }\end{aligned}$
\begin{tabular}{lll}
\hline GDL type & Manufacturer & Reference \\
\hline Toray H-120 & Toray & {$[15,37,99,101]$} \\
SGL GDLS & Sigracet & {$[97,104,181]$} \\
ELAT woven GDLS & E-TEK & {$[58,102]$} \\
Carbon cloth & & {$[98]$} \\
\hline
\end{tabular}




\begin{tabular}{lll}
\hline Properties & Units & 2015 DOE targets \\
\hline $\begin{array}{l}\text { Cost (based on 2002 \$ and volume } \\
\text { production of 500,000 stacks a year) }\end{array}$ & $\$ / \mathrm{kW}$ & 3 \\
Weight & $\mathrm{kg} / \mathrm{kW}$ & $<0.4$ \\
Electrical conductivity & $\mathrm{S} / \mathrm{cm}$ & $>100$ \\
Resistance (including contact resistance) & $\Omega \mathrm{cm}^{2}$ & $<0.01$ \\
Flexural strength (ASTM C-651-91) & $\mathrm{MPa}$ & $>25$ \\
Corrosion resistance & $\mathrm{A} \mathrm{cm}^{-2}$ & $<1 \times 10^{-6}$ \\
$\mathrm{H}_{2}$ permeability (at $80^{\circ} \mathrm{C}$ and 3 atm) & $\mathrm{cm}^{3} \mathrm{~cm}^{-2} \mathrm{~s}^{-1}$ & $<2 \times 10^{-6}$ \\
\hline
\end{tabular}

\begin{tabular}{|c|c|c|c|c|c|}
\hline Membrane material & GDL & Catalyst & Application & Hot press & Ref \\
\hline $\begin{array}{l}\text { PBI doped with phosphotungstic } \\
\text { acid and silicotungstic acid. }\end{array}$ & $\begin{array}{l}\text { Carbon cloth } \\
\text { (Etec Inc). }\end{array}$ & $\begin{array}{l}\text { Catalyst ink: Platinum on Vulcan } \\
\text { (XC- } 72 \text {, Etec Inc., } 20 \text { wt } \% \text { anode, } \\
40 \text { wt } \% \text { cathode), PBI binder } \\
\text { ( } 5 \text { wt } \% \text { in DMAc), DMAc solvent. } \\
\text { Pt loading: anode } 0.2 \mathrm{mg} \mathrm{cm}^{-2} \text {, } \\
\text { cathode } 0.4 \mathrm{mg} \mathrm{cm}^{-2} \text {. }\end{array}$ & $\begin{array}{l}\text { Airbrush application } \\
\text { onto GDL. Dried/sintered } \\
\text { at } 190^{\circ} \mathrm{C} \text { overnight. }\end{array}$ & $\begin{array}{l}\text { GDLs onto } \\
\text { membrane. } \\
110^{\circ} \mathrm{C}, 0.4 \\
\text { ton } \mathrm{cm}^{-2} \\
10 \mathrm{~min}\end{array}$ & [78] \\
\hline $\begin{array}{l}\text { Ternary blend of sulfonated } \\
\text { partially fluorinated arylene } \\
\text { poly ether } / \mathrm{PBI} / \mathrm{H}_{3} \mathrm{PO}_{4} \text {. }\end{array}$ & $\begin{array}{l}\text { Nonwoven, } \\
\text { pre-coated with a } \\
\text { micro-porous } \\
\text { layer (type not given). }\end{array}$ & $\begin{array}{l}\text { Catalyst ink: Platinum on carbon black } \\
\text { (HiSPECTM } 8000 \text {, Johnson Matthey) } \\
\text { Platinum catalysts, } 48.6 \text { wt\%), PBI } \\
\text { binder (Pt/PBI ratio } 13 \text { ), formic acid } \\
\text { and phosphoric acid solvent. Pt } \\
\text { loading: } 0.6-0.7 \mathrm{mg} \mathrm{cm}^{-2} \text {. }\end{array}$ & $\begin{array}{l}\text { Spray application onto } \\
\text { GDL. Dried at } 80^{\circ} \mathrm{C} \\
\text { for an hour. }\end{array}$ & $\begin{array}{l}\text { GDLs onto } \\
\text { membrane. } 200{ }^{\circ} \mathrm{C} \text {, } \\
0.1 \text { ton } \mathrm{cm}^{-2} \text {, } \\
10 \mathrm{~min} \text {. }\end{array}$ & [109] \\
\hline $\begin{array}{l}\text { Recast Nafion }{ }^{\infty} \text { doped with } \\
\text { sulfonated graphene oxide. }\end{array}$ & $\begin{array}{l}\text { No GDL - decal } \\
\text { method used. }\end{array}$ & $\begin{array}{l}\text { Catalyst ink: Platinum on carbon } \\
\text { (E-TEK, } 20 \text { wt } \% \text { ). } 5 \% \text { Nafion }{ }^{\infty} \text { binder, } \\
\text { glycerol solvent. Pt loading: anode } \\
0.1 \mathrm{mg} \mathrm{cm}^{-2} \text {, cathode } 0.2 \mathrm{mg} \mathrm{cm}^{-2} \text {. }\end{array}$ & $\begin{array}{l}\text { Catalyst ink painted onto } \\
\text { decal Teflon blanks. Dried } \\
\text { in oven. Repeated until } \\
\text { desired catalyst loading } \\
\text { achieved. }\end{array}$ & $\begin{array}{l}\text { Decals onto } \\
\text { membrane. } 210^{\circ} \mathrm{C} \text {, } \\
110 \mathrm{lbs} \mathrm{cm}^{-2}, 5 \mathrm{~min}\end{array}$ & [79] \\
\hline
\end{tabular}

By the utilization of the CCM method for the MEA preparation in the HT-PEMFC, it is possible to reduce this resistance due to the decrease in thickness of the catalyst layer leading to lowering the platinum loading and also by increasing the adhesion between the catalyst layer and the membrane [103]. Bonville et al. [111] utilised the CCM method in the preparation of their catalyst layers (a Nafion ${ }^{\circledR}$ e TeflonePTA membrane). When tested at a high temperature, they achieved good performance. The issues with using Nafion ${ }^{\circledR}$ at higher temperatures remain unresolved, for example Nafion ${ }^{\circledR}$ ionomer in the catalyst layer dehydrates and so loss of proton conductivity is observed. Further research is required to elucidate the effects of dehydration on the catalyst layer.

Alternative ionomers have been used in the MEA fabrication process. Lee et al. [112] were using a PBI based membrane and thus chose to use PBI ionomer along with Teflon in the catalyst layer. The platinum loading was $1 \mathrm{mg} \mathrm{cm}^{-2}$. Fig. 9 [112] shows how the different loadings of PBI ionomer in the catalyst layer affected the polarisation curve of the MEA. From the polarisation curve, the $5 \mathrm{wt} \%$ loading of PBI ionomer data gives the best results whereas the $10 \mathrm{wt} \%$ loadings seem to decrease the power output. This may be due to PBI being only poorly proton conducting by itself, requiring phosphoric acid to improve its proton conductivity thus leading to an overall decrease in the electrochemically active surface area. This was also seen to be the case when Lobato et al. [94] conducted tests on 
how the amount of PBI in the catalyst layer affected the electrochemical characteristics of it. Further research is required to see how the presence of phosphoric acid doped PBI in the catalyst layer can negatively affect the electrochemical characteristics of the platinum, especially at the cathode, due to the presence of water. Another large area of research is in novel ionomer materials, all of which need to be adaptable and be physically strong in both wet and dry conditions. The ionomer should be able to integrate well with the GDL as well as the membrane thus to allow for low interfacial resistance.

Once the MEA is prepared, it can be tested inside a fuel cell test stand. Table 10 shows some of the more promising membrane materials and the parameters used to show how they have met the DOE targets. It should be noted that the bulk measurements gained from in-situ testing can be crude as often several factors are contributing to a single result [113].

\subsection{Degradation}

Fuel cell durability is an essential parameter for fuel cell development. The acidic environment of the fuel cell combined with the humidity level and temperature creates a harsh environment for the components of the fuel cell. This environment results in degradation of fuel cell components and ultimately to loss of performance in the fuel cell. In HT-PEMFCs, the increase in temperature and the low humidity enhances the degradation rate. The lifetime of the fuel cell is one of the major challenges for HTPEMFCs. To the authors' knowledge, the longest lifetime reported for an HT-PEMFC is $18,000 \mathrm{~h}[114]$ under steady state conditions.

Low temperature PEMFC degradation mechanisms and testing have been extensively reviewed [115e118]. The same mechanisms can also be related to HT-PEMFCs and can be useful as references for future research. Shao et al. [37] reviewed the material challenges facing HT-PEMFC. The main problems reported in the literature are the loss in the catalyst active area due to catalyst agglomeration, and phosphoric acid leaching out from the cell [37,119,120]. It is the opinion of Yu et al. [121] and Wannek et al. [122] that the main source of performance loss is due to catalyst agglomeration.

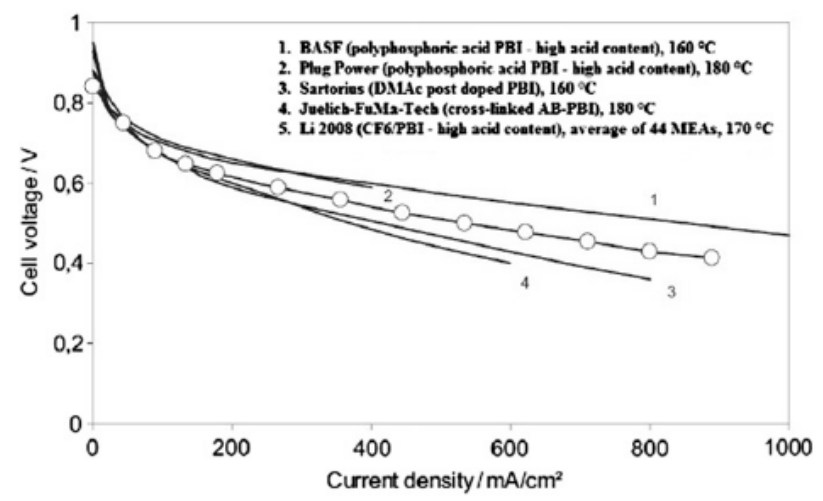

Fig. 8. The single cell performance of different types of PBI materials under similar conditions [109]. 


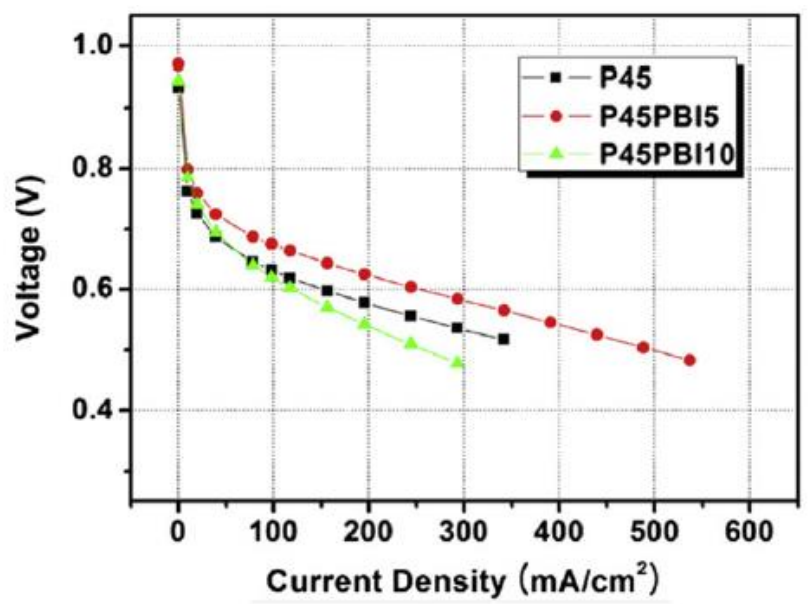

Fig. 9. The current density when $5 \mathrm{wt} \% \mathrm{~m}-\mathrm{PBI}, 10 \mathrm{wt} \% \mathrm{~m}-\mathrm{PBI}$ and no $\mathrm{m}-\mathrm{PBI}$ were used in the electrode [112].

Moçotéguy et al. [123] reported steady-state long term testing for a single cell and a $500 \mathrm{~W}$ stack with pure and simulated reformate fuel. They achieved 1105 and $658 \mathrm{~h}$ for the single cell and the stack, respectively. $\mathrm{Hu}$ et al. [97] ran a $\mathrm{PBI} / \mathrm{H}_{3} \mathrm{PO}_{4}$ membrane fuel cell for 500 $\mathrm{h}$ under steady-state conditions at constant current. The test showed that for the first $100 \mathrm{~h}$ the cell was in activation phase, and then went into the degradation phase. They also found that the cathode catalyst particle size grew from $3.8 \mathrm{~nm}$ to $6.9 \mathrm{~nm}$. This is corroborated by Zhai et al. [104] who reported a loss in catalyst stability at high temperature resulting in 55\% loss in the Electrode Surface Area due to agglomeration.

$\mathrm{Yu}$ et al. [121] studied phosphoric acid leaching from the membrane under steady-state conditions and reported that the level of leaching of the acid is very low which indicates a capability of operation for over 10,000 h. However, leaching was found to be dependent on temperature and load conditions and it mainly occurs on the cathode side [121]. An increase in the cell resistance due to loss of membrane conductivity was observed in the fuel cell due to the loss of $\mathrm{H}_{3} \mathrm{PO}_{4}$ [97,119]. Also, delamination of MEA components occurs due to the hydrate expansion difference which is reported in [97,124], however, the gap was filled with $\mathrm{H}_{3} \mathrm{PO}_{4}$ that acted as an electrolyte and prevented any change in the cells performance [97].

Other lifetime related studies are reported in the literature; Cheng et al. [125] studied hydrogen crossover in HT-PEMFCs, and degradation in the PBI-membrane has been reported due to hydrogen peroxide formation [120]. Moçotéguy et al. [123] studied the effect of using reformate fuel reporting a loss of 70e90\% of the anode catalyst surface area due to the presence of $\mathrm{CO}$. Moreover, carbon support corrosion and membrane oxidation were reported to be enhanced in HT-PEMs increasing the durability challenge [114]. From all of the studies shown, it can be seen that the catalyst sintering and agglomeration is one of the biggest challenges to the long-term durability of the HT-PEM, especially if an acidebase system is used. Thus, for significant improvements in the longevity of the HT-PEM, the main focus of research should be in the membrane materials and the catalyst layer stability. 


\subsection{Stack design}

When investigating the PEMFC, a lot of information can be gained from the study of a single cell. Usually, it is the case that single cells must be joined in series in order to meet the power demands of various applications, for example to power a vehicle. This is known as the PEMFC stack. As the stack increases in size, so does the complexity of the system as a whole as, the voltage, power capacity and balance of plant must be addressed $[126,127]$. A single cell is quite simple in terms of fuel and air supply, however in a PEMFC stack, fuel and air delivery requires a gas manifold as well as for the removal of waste water and heat [128]. The methodology of reactant delivery and cell design are therefore of paramount importance as poorly distributed fuel and resistance due to the cell configuration often leads to uneven temperature and voltage across the stack thus leading to a drop in the cell performance [129e131]. As with many engineering problems, it is always important to question how accurate it is to use how a small scale model operates when considering scale up. In the case of fuel cells, the question is how accurate is the scenario of a single cell when considering the processes occurring in a stack. Chu et al. [127] compared the Open Circuit Voltage, Tafel slope and electrical resistance of a single cell and a 30 cell-stack. They found that these values for the stack seemed to be a simple addition of the single cell values however they concluded that mass transfer behaviour of the stack is more complicated, as would be expected. Bonnet et al. [126] conducted a similar study into the effects of scale up when designing an 8o kW PEMFC stack. They compared results for a 25 $\mathrm{cm}^{2}$ single cell, a 5 cell stack and a 90 cell stack. They found that the polarisation curves (see Fig. 10 [111]) for the three different sizes seemed to be in concordance thus suggesting that a single cell can be used to predict stack behaviour.

\begin{tabular}{|c|c|c|c|c|c|c|c|}
\hline MEA & $\begin{array}{l}\text { Active } \\
\text { area } / \mathrm{cm}^{2}\end{array}$ & FFP & $\begin{array}{l}\text { Temperature } \\
\text { regulation }\end{array}$ & $\begin{array}{l}\text { Current } \\
\text { collection }\end{array}$ & Fuel gas/Stoichiometric & Notes & Ref \\
\hline $\begin{array}{l}\text { PBI doped with } \\
\text { phosphotungstic } \\
\text { acid and silicotungstic } \\
\text { acid. }\end{array}$ & 1 & $\begin{array}{l}\text { High-density } \\
\text { graphite } \\
\text { impregnated } \\
\text { with phenolic } \\
\text { resin. Parallel flow } \\
\text { channels. }\end{array}$ & $\begin{array}{l}\text { Electric cartridge } \\
\text { heaters thermocouples } \\
\text { temperature controller. }\end{array}$ & $\begin{array}{l}\text { Gold-plated } \\
\text { steel bolts }\end{array}$ & $\begin{array}{l}\text { Hydrogen and oxygen as } \\
\text { dry gases at atmospheric } \\
\text { pressure. Flow rates in } \\
\text { excess of stoichiometric } \\
\text { requirements. }\end{array}$ & & {$[78]$} \\
\hline $\begin{array}{l}\text { SPESK block co-polymer } \\
\text { with sulfonated } \\
\text { fluorene groups. }\end{array}$ & 3.8 (circular) & & & & $\begin{array}{l}200 \mathrm{~mL} \mathrm{~min}^{-1} \text { for } \\
\text { both electrodes }\end{array}$ & $\begin{array}{l}\text { Circular cell } \\
\text { with a reversible } \\
\text { hydrogen electrode. }\end{array}$ & {$[80]$} \\
\hline $\begin{array}{l}\text { Ternary blend of sulfonated } \\
\text { partially fluorinated } \\
\text { arylene poly ether } \\
/ \mathrm{PBI} / \mathrm{H}_{3} \mathrm{PO}_{4} \text {. }\end{array}$ & 16 & $\begin{array}{l}\text { Graphite plates. } \\
\text { Parallel gas channels } \\
\text { of } 2 \mathrm{~mm} \text { width and } \\
1 \mathrm{~mm} \text { depth with } \\
\text { ribs of } 1 \mathrm{~mm} \text { width. }\end{array}$ & $\begin{array}{l}\text { Heaters attached } \\
\text { to two stainless } \\
\text { steel end plates } \\
\text { also serves as } \\
\text { current collector. }\end{array}$ & & $\begin{array}{l}\text { Hydrogen and oxygen as } \\
\text { dry gases at atmospheric } \\
\text { pressure. }\end{array}$ & & [109] \\
\hline $\begin{array}{l}\text { Recast Nafion } \\
\text { doped with } \\
\text { sulfonated graphene } \\
\text { oxide. }\end{array}$ & 5 & & & & $\begin{array}{l}0.2 \text { and } 0.5 \mathrm{~L} \mathrm{~min}^{-1} \text { hydrogen } \\
\text { and oxygen respectively }\end{array}$ & & [79] \\
\hline
\end{tabular}

When studying the single cell and the 5 cell stack in further detail, they found that the effect of fuel flow had little effect on the cell voltages. Moving from single cell to stack operation is favourable due to the possibilities for greater fuel economy and power capabilities [127]. For LT-PEMFC systems, it is of paramount importance to have excellent water and thermal management systems in place to accommodate the non- 
uniformity of the cell potential, reactant concentration and temperature [132]. Theoretically, by switching to high temperature operation, the water and thermal management should be easier as there is only a single phase of water vapour and a more significant temperature gradient.

In contrast, it has also been shown that a single cell cannot be used to predict the behaviour of a stack. Urbani et al. [133] found that the relative humidity at the anode and cathode caused a difference in the polarisation curves of a single cell and a 5 cell stack. When a high relative humidity was used at both the anode and the cathode, they also found that the stack performance suffered due to flooding of the cells. When the cell and stack were run at $80^{\circ} \mathrm{C}$, fuel and air pressure were at $1.5 \mathrm{bar}$ and a current of $0.4 \mathrm{~A} \mathrm{~cm}^{-}$ 2 was drawn, they found an $8 \%$ decrease in the performance of the stack [111].

Another area where a single cell behaviour cannot be used to predict stack behaviour is heat management. Chu et al. [127] found this when studying a 30 cell stack. Due to the large number of cells, an even heating effect could not easily be applied to the cells and heat generated from the fuel cell reactions was very difficult to remove from the interior of the stack. This resulted in a difference of $26^{\circ} \mathrm{C}$ from the interior of the stack to the exterior.

Very little work has been conducted into whether or not an HT-PEM single cell results will allow for accurate prediction of the behaviour of a stack. In particular, the fact that there will be simpler water and heat management will mean that small scale studies should have greater validity as the mass transport problems that plague LT-PEMFC systems should not be an issue. Further research is required to see if this is true. It would also be of interest to see if an HT-PEM small stack could be used to predict the behaviour of a larger stack. In LT-PEMFC systems, it was found [128,134e136] that small scale stacks could be used to predict the behaviour of larger scale stacks although it was acknowledged that BoP was very different for different sizes of stack, for example San Martin et al. [134] found that a $1 \mathrm{~kW}$ stack required both an air compressor and cooling fan while the cooling fan was the only requirement for a $40 \mathrm{~kW}$ stack. Due to the simplification of high temperature operation, it would be beneficial to see how the BoP requirements change as the stack is increased in size.

Cooling of the stack is one of the big design considerations when developing a stack for a particular application. There are two main types of cooling infrastructure that are used within the stack: (i) the air/cathode cooling system and (ii) the liquid cooling system. The principle behind the air/cathode cooling system is that the cathode or air gas is also used to remove the heat generated by the stack. This is often the cheaper method of cooling the stack as the only balance of plant required is an air pump to pass air though the cell [137,138]. Depending on the size of the stack, this pump would already be present so not much modification is required. The downside of this type of cooling system is that it is not suitable for large power applications as the parasitic drain on power becomes too high. On the other hand, the liquid cooling system works by the introduction of cooling 
plates in the stack $[139,140]$. A liquid is pumped through these channels and heat is removed from the stack by this heat exchanger effect. This type of cooling is suitable for large scale stacks as scaling up this liquid cooling system does not increase the power demands of the balance of plant significantly, furthermore the coolant could be integrated into other systems, for example refrigeration systems, to allow the waste heat to be used for an otherwise energy intensive purpose [141].

One of the major differences between high temperature and low temperature operation is the required levels of cooling in the stack. LT-PEMFCs require a greater level of cooling due to the lack of a sufficient temperature gradient for passive cooling. This close control of temperature is further complicated by the relative humidity requirements of the membrane [127]. In LT-PEMFC stacks, the waste heat is taken away through a heat exchange process, either by air cooling or liquid cooling, and then can be used in the humidification process for the inlet hydrogen streams. By recycling this heat it is possible to drastically increase the fuel cell efficiency. Giddey et al. [135] constructed a $1 \mathrm{~kW}$ LT-PEMFC stack system and calculated the various efficiencies. They found that on average, their stack operated at $41 \%$ efficiency when the generated heat was not recycled but when used in a CHP capacity, efficiencies of $80 \%$ were recorded. In an anhydrous HT-PEMFC system, with PBI or ionic liquid membrane material, there is no need for this humidification process. Due to the high temperature operation, it is not necessary to actively cool the cells in the same way as an LT-PEMFC system [142]. If the HT-PEMFC stack is being used in a stationary power generation capacity then it may be possible for the waste heat to be used for CHP. In a transport application, it may be possible to remove the heat by integrating the stack cooling system with the existing engine cooling infrastructure. Further research is required to identify the optimum cooling method for vehicular applications. Another major issue with stack design for LT-PEMFC is that water management is difficult to balance [143]. Too little water and the membrane dehydrates, which causes a decrease in the fuel cell performance. Too much water and the electrocatalyst layer will flood which leads to a decrease in the fuel cell performance. As a result, design of the flow fields [93] and the material selection for the GDL is of paramount importance. When higher operating temperatures are used in the stack, the reaction product is water in the gas phase and as such it is much simpler to remove through a passive diffusion process. This is advantageous for several reasons, for example the design of the flow field plates becomes simpler which means that the stack design can be simplified [93]. However, it must be noted that the higher temperature will result in higher rates of degradation for the individual materials. Further research would be required into how the water level will affect the stack performance.

The fuel cell stack consists of a number of single cells being joined in series. Practically, this means that the cathode of one cell is connected to the anode of the adjacent cell. The most common configuration is the bipolar stack (see Fig. 11). 


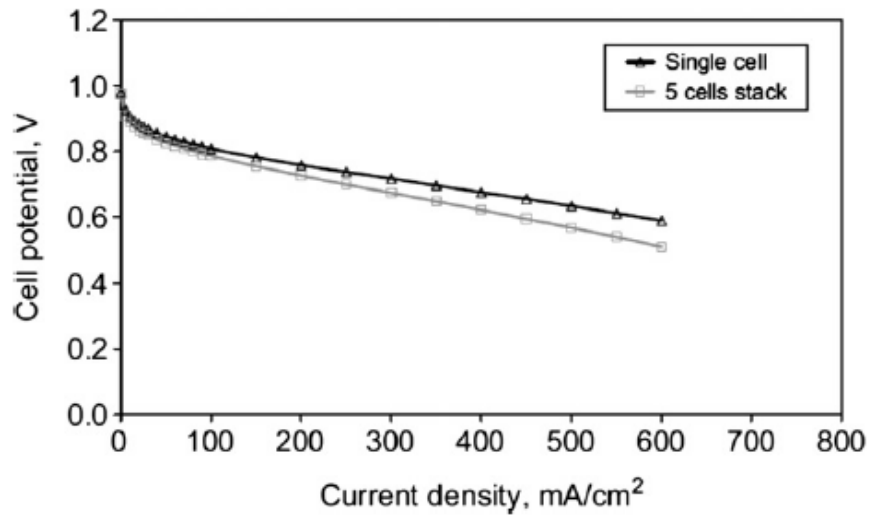

Fig. 10. Polarisation curve comparison for single cell and a 5 cell pilot stack.

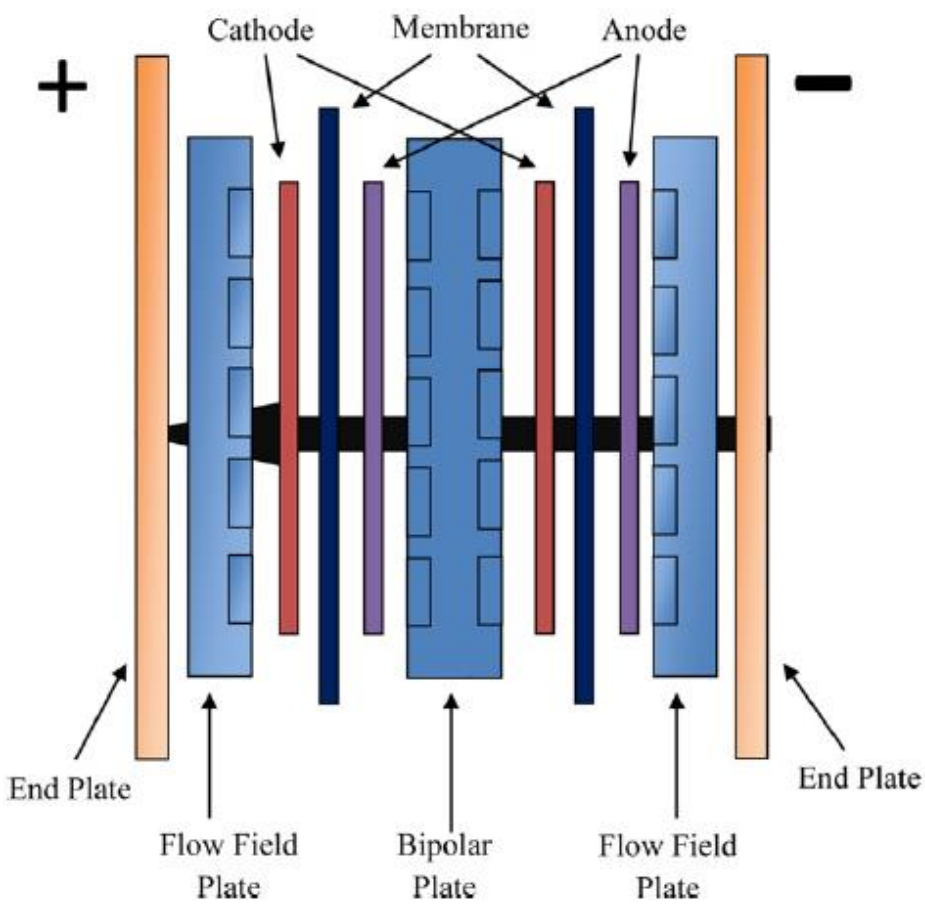

Fig. 11. Bipolar plate configuration.

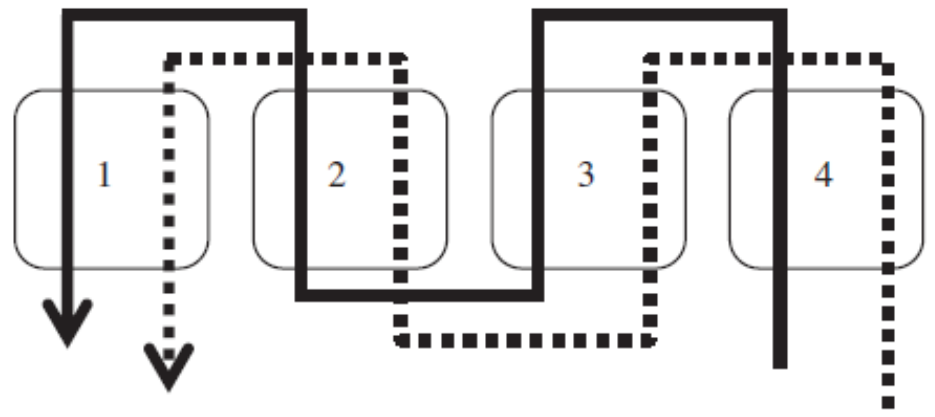

Fig 12. An example of serial flow configuration. 
The Bipolar Configuration (BPC) is best for larger stacks because of the relatively low resistance of the bipolar plates (BPPs), and a relatively large surface area for the electrons to travel through. The main issue with this type of configuration is the cost of the BPPs. Further R\&D into the materials and the design of the BPP are required in order to further reduce the costs of the $\mathrm{BPC}$ [144].

One of the main advantages of the LT-PEMFC system is that it can be heated up relatively rapidly due to its low operating temperature. Andreasen et al. [145] studied the different heating strategies available for an HT-PEMFC stack in order to determine which method was best for rapid start-up. If an acid doped PBI based membrane is used in the fuel cell it is of paramount importance to avoid drawing a current before a temperature of $100{ }^{\circ} \mathrm{C}$ has been reached. This is to stop the leaching of the acid from the membrane by the presence of liquid water in the MEA [145]. Andreasen et al. [145] primarily studied two heating strategies. First, they tried using external heaters and found the start up time was in the region of an hour. Next they tried using preheated fuel, which sped the start-up time to 6 min, overall a 90\% drop in start-up time. Further work is required to investigate whether enhanced design of the BPP incorporating embedded heating filaments would allow for an even faster start up time.

The internal gas flow configuration has also been found to have an effect on the performance of the fuel cell stack. Friedl et al. [146] found that, for a 6-cell system, having a mixture of gas flows (parallel gas flow configuration as well as serial gas flow configuration) showed the highest average cell output voltage in the majority of their measurements. They found that having gas flow in cells in a uniformly serial fashion (see Fig. 12) gave the largest variation in terms of average cell voltage. This is most likely due to the large pressure drop in the flow channel, which causes differences in the local reactant concentrations thus causing the difference in the cell voltages.

One of the many disadvantages found with LT-PEMFC stack operation is the degradation rates due to the presence of liquid water in the stack system. By switching to high temperature operation this is simplified because there is no liquid water present in the stack. The field of stack design for high temperature is still a relatively new one with only one company (Serenergy A/S) currently commercially selling HT-PEMFC stacks. Further research is required to investigate the best configuration of gas flow, novel methods of heating for a rapid start-up sequence, novel methods of cooling and lowering the cost of the BoP, all of which should help to improve individual cell potential uniformity and lead to a more efficient stack.

\section{Conclusions}

Much effort has been put into research of the HT-PEMFC, which has led to some breakthroughs in the field. A majority of the research has been focused on the membrane, as many researchers see this as the biggest barrier to the widespread commercialisation of the HT-PEMFC. In particular, there is a large deficit in well performing materials that meet all of the DOE targets, for the operating temperature 
between 80 and $130{ }^{\circ} \mathrm{C}$ (the so-called intermediate temperatures). Above this intermediate zone, the acid doped membranes clearly dominate the field, with their ability to completely scrap any humidification system and high tolerance to impure fuel. However, these membranes also have a host of issues, for example, the propensity of the acid to leach which increases the complexity of system design and the high temperature means long start up times, which is unacceptable to the transport industry. As such, for future use, a compromise must be reached which means a lower operating temperature and novel membrane materials.

There is also much promise with the catalyst layer as lower loadings and alternative catalysts can be used at the higher temperatures. There still remain the issues of the catalyst and catalyst layer durability, especially with the acidebase systems and the acids tend to accelerate the aging of the catalysts that are used. Current state-of-the-art GDL and FFP materials appear to meet the targets, and research for LT-PEMFCs feeds in nicely as materials that are used for LT and HT are the same. However, there is still room for improvement, for example, novel coatings on the FFP need to be investigated in order to improve the durability of the FFP in a high temperature environment, whether that is an acidebase system or a water based system. Finally, stack development for the HT-PEM field is still very important but is very much dependant on the membrane choice. For example, if an acidebase system is chosen, the stack materials and design needs to be optimised in order to minimise the effects of leaching and to improve the start-up times.

The success of the HT-PEMFC direction is very much dependant on the development of the membrane material, followed by the optimisation of the MEA. This will determine a whole range of other factors, for example, the MEA fabrication technique, the FFP material choice, the stack design, the system design, etc. Currently, the only membrane material to come close to meeting all of the DOE targets at high temperature (apart from durability) is acid doped PBI; however it works at a temperature that is unsuitable for mobile applications. It currently seems that there are no materials that work at high temperature without the need for humidification apart from acid doped PBI or ioniceliquid doped materials. For transport applications, it appears that the trend has veered towards intermediate temperatures with some humidification always being required. 


\section{References}

[1] C. Wieser, Fuel Cells 4 (2004) 245e250.

[2] R. Devanathan, Energy \& Environmental Science 1 (2008) $101 \mathrm{e} 119$.

[3] J. Jagur-Grodizinski, Polymers for Advanced Technologies 18 (2007) $785 \mathrm{e} 799$.

[4] Y.-G. Chun, C.-S. Kim, D.-H. Peck, D.-R. Shin, Journal of Power Sources 71 (1998) $174 \mathrm{e} 178$.

[5] A. Therdthianwong, P. Saenwiset, S. Therdthianwong, Fuel 91 (2012) $192 \mathrm{e} 199$.

[6] B. Millington, S. Du, B.G. Pollet, Journal of Power Sources 196 (2011) 9013e 9017.

[7] R. Taccani, N. Zuliani, International Journal of Hydrogen Energy 36 (2011) $10282 \mathrm{e} 10287$.

[8] J.A. Asensio, E.M. Sanchez, P. Gomez-Romero, Chemical Society Reviews 39 (2010) 3210e3239.

[9] X. Glipa, A. Hogarth, in, Johnson Matthey Technology Centre (2001) 1 e68. [10] P. Costamagna, C. Yang, A.B. Bocarsly, S. Srinivasan, Electrochimica Acta 47

(2002) 1023e1033.

[11] S. Reichman, A. Ulus, E. Peled, Journal of The Electrochemical Society 154 (2007) B327eB333.

[12] M. Rikukawa, K. Sanui, Progress in Polymer Science 25 (2000) 1463 e1502. [13] C. Yang, P. Costamagna, S. Srinivasan, J. Benziger, A.B. Bocarsly, Journal of Power Sources 103 (2001) 1 e9.

[14] Q. Li, R. He, J.O. Jensen, N.J. Bjerrum, Chemistry of Materials 15 (2003) 4896e 4915 .

[15] C. Pan, R. He, Q. Li, J.O. Jensen, N.J. Bjerrum, H.A. Hjulmand, A.B. Jensen, Journal of Power Sources 145 (2005) $392 \mathrm{e} 398$.

[16] Q. Li, H. Ronghuan, G. Ji-An, J.O. Jensen, N.J. Bjerrum, Journal of the Electrochemical Society 150 (2003) A1599eA1605.

[17] M. Martinez, Y. Molmeret, L. Cointeaux, C. Iojoiu, J.-C. Leprêtre, N. El Kissi, P. Judeinstein, J.-Y. Sanchez, Journal of Power Sources 195 (2010) 5829e 5839.

[18] D. Villers, X. Jacques-Bedard, J.P. Dodelet, Journal of the Electrochemical Society 151 (2004) A1507eA1515.

[19] H.-S. Oh, J.-G. Oh, B. Roh, I. Hwang, H. Kim, Development of highly active and stable non-precious oxygen reduction catalysts for PEM fuel cells using polypyrrole and a chelating agent, Electrochemistry Communications 13 (2011) $879 \mathrm{e} 881$.

[20] S. Bose, T. Kuila, T.X.H. Nguyen, N.H. Kim, K.-t. Lau, J.H. Lee, Polymer membranes for high temperature proton exchange membrane fuel cell: Recent advances and challenges, Progress in Polymer Science 36 (2011) 813 e843. [21] L. Avery, in, Department for Transport (2009).

[22] Y. Wang, K.S. Chen, J. Mishler, S.C. Cho, X.C. Adroher, Applied Energy 88 (2011). 
[23] J.K. Kallitsis, M. Geormezi, S.G. Neophytides, Polymer International 58 (2009) 1226e1233.

[24] K. Miyatake, M. Watanabe, Electrochemistry 73 (2005) $12 \mathrm{e} 19$.

[25] S.J. Hamrock, M.A. Yandrasits, Polymer Reviews 46 (2006) 219 e244.

[26] M. Mamlouk, K. Scott, International Journal of Energy Research 35 (2011) $507 \mathrm{e} 519$.

[27] E.J. Carlson, P. Kopf, J. Sinha, S. Sriramulu, Y. Yang, in, National Renewable Energy Laboratory, 2005.

[28] J. Spendelow, J. Marcinkoski, in, DOE (2009).

[29] O.o.E.E.a.R, Energy, U.S. Department of Energy, Washington, 2011. [30] A.-C. Dupuis, Progress in Materials Science 56 (2011) 289e327. [31] H. Bai, W.S.W. Ho, Polymer International 60 (2011) $26 \mathrm{e} 41$.

[32] S.J. Peighambardoust, S. Rowshanzamir, M. Amjadi, International Journal of Hydrogen Energy 35 (2010) 9349e9384.

[33] N. Gourdoupi, J.K. Kallitsis, S. Neophytides, Journal of Power Sources 195 (2010) $170 \mathrm{e} 174$.

[34] S.M.J. Zaidi, Research Trends in Polymer Electrolyte Membranes for PEMFC, Springer Science p Business Media, 2009.

[35] R.H. Puffer, S.J. Rock, Journal of Fuel Cell Science and Technology 6 (2009). [36] K.E. Martin, J.P. Kopasz, Fuel Cells 9 (2009) $356 e 362$.

[37] Y. Shao, G. Yin, Z. Wang, Y. Gao, Journal of Power Sources 167 (2007) $235 \mathrm{e} 242$.

[38] K. Miyatake, M. Watanabe, Journal of Materials Chemistry 16 (2006) 4465 e 4467.

[39] B. Smitha, S. Sridhar, A.A. Khan, Journal of Membrane Science 259 (2005) $10 \mathrm{e} 26$.

[40] M.E. Schuster, W.H. Meyer, Annual Review of Materials Research 33 (2003) $233 \mathrm{e} 261$.

[41] J. Roziere, D.J. Jones, Annual Review of Materials Research 33 (2003) 503e555. [42] V. Mehta, J.S. Cooper, Journal of Power Sources 114 (2003) $32 \mathrm{e} 53$.

[43] A. Glusen, D. Stolten, Chemie Ingenieur Technik 75 (2003) $1591 e 1597$. [44] J.A. Kerres, Journal of Membrane Science 185 (2001) 3 e27.

[45] P. Costamagna, S. Srinivasan, Journal of Power Sources 102 (2001) $242 \mathrm{e} 252$.

[46] C.H. Park, C.H. Lee, M.D. Guiver, Y.M. Lee, Progress in Polymer Science 36 (2011) $1443 \mathrm{e} 1498$.

[47] A. El-Kharouf, A. Chandan, M. Hattenberger, B.G. Pollet, Proton exchange membrane fuel cell degradation and testing: review, Journal of the Energy Institute 85 (2012) 188e200.

[48] S.Z. Yi, F.F. Zhang, W. Li, C. Huang, H.N. Zhang, M. Pan, Journal of Membrane Science 366 (2011) 349e355.

[49] W.H.J. Hogarth, J.C. Diniz da Costa, G.Q. Lu, Journal of Power Sources 142 (2005) $223 \mathrm{e} 237$. 
[50] Y.L. Ma, J.S. Wainright, M.H. Litt, R.F. Savinell, Journal of The Electrochemical Society 151 (2004) A8eA16.

[51] M.K. Mistry, S. Subianto, N.R. Choudhury, N.K. Dutta, Langmuir 25 (2009) $9240 e 9251$.

[52] R. Souzy, B. Ameduri, Progress in Polymer Science 30 (2005) 644e687.

[53] A. Stassi, I. Gatto, E. Passalacqua, V. Antonucci, A.S. Arico, L. Merlo, C. Oldani, E. Pagano, Journal of Power Sources 196 (2011) 8925e8930.

[54] A.S. Arico, A. Stassi, E. Modica, R. Ornelas, I. Gatto, E. Passalacqua, V. Antonucci, Journal of Power Sources 178 (2008) 525e536.

[55] Z. Tu, H. Zhang, Z. Luo, J. Liu, Z. Wan, M. Pan, Journal of Power Sources 222 (2013) 277e281.

[56] K.D. Kreuer, M. Schuster, B. Obliers, O. Diat, U. Traub, A. Fuchs, U. Klock, S.J. Paddison, J. Maier, Journal of Power Sources 178 (2008) 499e509.

[57] C. Wannek, W. Lehnert, J. Mergel, Journal of Power Sources 192 (2009) $258 \mathrm{e} 266$.

[58] Q. Li, J.O. Jensen, R.F. Savinell, N.J. Bjerrum, Progress in Polymer Science 34 (2009) $449 \mathrm{e} 477$.

[59] H.L. Lin, Y.C. Chou, T.L. Yu, S.W. Lai, International Journal of Hydrogen Energy 37 (2012) 383e392.

[6o] S. Wang, G. Zhang, M. Han, H. Li, Y. Zhang, J. Ni, W. Ma, M. Li, J. Wang, Z. Liu, L. Zhang, H. Na, International Journal of Hydrogen Energy 36 (2011) 8412e 8421.

[61] M.M. Han, G. Zhang, Z.G. Liu, S.A. Wang, M.Y. Li, J. Zhu, H.T. Li, Y. Zhang, C.M. Lew, H. Na, Journal of Materials Chemistry 21 (2011) $2187 e 2193$.

[62] S.K. Kim, S.W. Choi, W.S. Jeon, J.O. Park, T. Ko, H. Chang, J.C. Lee, Macromolecules 45 (2012) $1438 \mathrm{e} 1446$.

[63] D. Aili, Q.F. Li, E. Christensen, J.O. Jensen, N.J. Bjerrum, Polymer International 60 (2011) $1201 \mathrm{e} 1207$.

[64] L. Sheng, H.J. Xu, X.X. Guo, J.H. Fang, L.A. Fang, J. Yin, Journal of Power Sources 196 (2011) 3039e3047.

[65] J.A. Mader, B.C. Benicewicz, Fuel Cells 11 (2011) $222 e 237$.

[66] J.A. Mader, B.C. Benicewicz, Macromolecules 43 (2010) 6706e6715.

[67] R.L. Thankamony, J.M. Hwang, T.H. Kim, Journal of Membrane Science 392 (2012) $58 \mathrm{e} 65$.

[68] K. Miyatake, T. Yasuda, M. Watanabe, Journal of Polymer Science Part APolymer Chemistry 46 (2008) $4469 \mathrm{e} 4478$.

[69] Y. Devrim, S. Erkan, N. Bac, I. Eroglu, International Journal of Hydrogen Energy 34 (2009) 3467 e3475.

[70] C. Iojoiu, J.Y. Sanchez, High Performance Polymers 21 (2009) 673 e692.

[71] B.P. Tripathi, V.K. Shahi, Organic-inorganic nanocomposite polymer electrolyte membranes for fuel cell applications, Progress in Polymer Science 36 (2011) 945e979.

[72] C. Laberty-Robert, K. Valle, F. Pereira, C. Sanchez, Chemical Society Reviews 40 (2011) 961e1005. 
[73] S.M. Haile, D.A. Boysen, C.R.I. Chisholm, R.B. Merle, Nature 410 (2001) 910e913. [74] J.H. Piao, S.J. Liao, Z.X. Liang, Journal of Power Sources 193 (2009) 483e487. [75] E.M. Tsui, M.M. Cortalezzi, M.R. Wiesner, Journal of Membrane Science 306 (2007) 8e15.

[76] S. Kaliaguine, S.D. Mikhailenko, K.P. Wang, P. Xing, G. Robertson, M. Guiver, Catalysis Today 82 (2003) $213 \mathrm{e} 222$.

[77] C. Wannek, I. Konradi, J. Mergel, W. Lehnert, International Journal of Hydrogen Energy 34 (2009) 9479e9485.

[78] A. Verma, K. Scott, Journal of Solid State Electrochemistry 14 (2010) 213 e219. [79] H. Zarrin, D. Higgins, Y. Jun, Z. Chen, M. Fowler, The Journal of Physical Chemistry C 115 (2011) 20774e20781.

[80] B. Bae, T. Yoda, K. Miyatake, M. Uchida, H. Uchida, M. Watanabe, Journal of Physical Chemistry B 114 (2010) 10481 e10487.

[81] U.S.D.o, Energy, US DOE, 2010.

[82] D. Larminie, in.

[83] B. Avasarala, R. Moore, P. Haldar, Electrochimica Acta 55 (2010) 4765e4771. [84] P.J. Ferreira, G.J. la O, Y. Shao-Horn, D. Morgan, R. Makharia, S. Kocha,

H.A. Gasteiger, Journal of the Electrochemical Society 152 (2005) A2256e A2271.

[85] H. Yuan, H. Song, X. Qiu, W. Zhu, L. Chen, Electrochemistry Communications 12 (2010) $14 \mathrm{e} 17$.

[86] O.J. Curnick, P.M. Mendes, B.G. Pollet, Electrochemistry Communications 12 (2010) 1017e1020.

[87] C. lamy, D.J. Jones, C. Coutanceau, P. Brault, S. Martemianov, Y. Bultel, Electrochimica Acta, 2010.

[88] P.C. Jennings, B.G. Pollet, R.L. Johnston, Physical Chemistry Chemical Physics, 2012.

[89] Q. Zeng, L. Zheng, J. Zeng, S. Liao, Journal of Power Sources 205 (2012) $201 \mathrm{e} 206$.

[90]

ndo, F. Mijangos, B. Rambabu, Journal of Power Sources 195

(2010)

3977 e3983.

[91] A. El-kharouf, B.G. Pollet, Chapter 4-gas diffusion media and their degradation, in: Polymer Electrolyte Fuel Cell Degradation, Academic Press, Boston, 2012, pp. $215 \mathrm{e} 247$.

[92] J. Lobato, P. Cañizares, M.A. Rodrigo, C. Ruiz-López, J.J. Linares, Journal of Applied Electrochemistry 38 (2008) $793 \mathrm{e} 802$.

[93] P.J. Hamilton, B.G. Pollet, Fuel Cells 10 (2010) 489 e509.

[94] J. Lobato, P. Cañizares, M.A. Rodrigo, J.J. Linares, F.J. Pinar, International Journal of Hydrogen Energy 35 (2010) 1347e1355.

[95] T. Sousa, M. Mamlouk, K. Scott, C.M. Rangel, Fuel Cells 12 (2012) 566e576. [96] C. Pan, Q. Li, J.O. Jensen, R. He, L.N. Cleemann, M.S. Nilsson, N.J. Bjerrum, 
Q. Zeng, Journal of Power Sources 172 (2007) 278e286.

[97] J. Hu, H. Zhang, Y. Zhai, G. Liu, J. Hu, B. Yi, Electrochimica Acta 52 (2006) $394 \mathrm{e} 401$.

[98] P. Krishnan, J.-S. Park, C.-S. Kim, Journal of Power Sources 159 (2006) 817e823. [99]

Y. Song, Y. Wei, H. Xu, M. Williams, Y. Liu, L.J. Bonville, H. Russell Kunz,

J.M. Fenton, Journal of Power Sources 141 (2005) $250 e 257$.

[100] F. Seland, T. Berning, B. Børresen, R. Tunold, Journal of Power Sources 160 (2006) $27 \mathrm{e} 36$.

[101] J. Lobato, P. Canizares, M.A. Rodrigo, J.J. Linares, J.A. Aguilar, Journal of Membrane Science 306 (2007) 47e55.

[102] S.-Y. Lee, T. Yasuda, M. Watanabe, Journal of Power Sources 195 (2010) $5909 \mathrm{e} 5914$.

[103] J. Zhang, Z. Xie, J. Zhang, Y. Tang, C. Song, T. Navessin, Z. Shi, D. Song, H. Wang, D.P. Wilkinson, Z.-S. Liu, S. Holdcroft, Journal of Power Sources 160 (2006) $872 \mathrm{e} 891$.

[104] Y. Zhai, H. Zhang, D. Xing, Z.-G. Shao, Journal of Power Sources 164 (2007) $126 \mathrm{e} 133$.

[105] C. Hartnig, T.J. Schmidt, Electrochimica Acta 56 (2011) 4237e4242. [106] S. Sharma, B.G. Pollet, Journal of Power Sources 208 (2012) 96e119.

[107] E.A. Ticianelli, C.R. Derouin, S. Srinivasan, Journal of Electroanalytical Chemistry and Interfacial Electrochemistry 251 (1988) $275 \mathrm{e} 295$.

[108] H.A. Gasteiger, J.E. Panels, S.G. Yan, Journal of Power Sources 127 (2004) $162 \mathrm{e} 171$.

[109] Q. Li, J.O. Jensen, C. Pan, V. Bandur, M.S. Nilsson, F. Schonberger, A. Chromik,

M. Hein, T. Haring, J. Kerres, N.J. Bjerrum, Fuel Cells 8 (2008) 188e199. [110] E. Novillo, M. Pardo, A. Garcia-Luis, Journal of Fuel Cell Science and Technology 8 (2011).

[111] L.J. Bonville, H.R. Kunz, Y. Song, A. Mientek, M. Williams, A. Ching, J.M. Fenton, Journal of Power Sources 144 (2005) $107 e 112$.

[112] H.-J. Lee, B.G. Kim, D.H. Lee, S.J. Park, Y. Kim, J.W. Lee, D. Henkensmeier, S.W. Nam, H.-J. Kim, H. Kim, J.-Y. Kim, International Journal of Hydrogen Energy 36 (2011) 5521e5526.

[113] D.J.L. Brett, A.R. Kucernak, P. Aguiar, S.. Atkins, N.P. Brandon, R. Clague, L.F. Cohen, G. Hinds, C. Kalyvas, G.J. Offer, B. Ladewig, R. Maher, A. Marquis, P. Shearing, N. Vasileiadis, V. Vesovic, ChemPhysChem 11 (2010) 2714e2731. [114] J.O. Jensen, Q. Li, C. Pan, N.J. Bjerrum, H.C. Rudbeck, T. Steenberg, in: 18th World Hydrogen Energy Conference, 2010.

[115] S. Zhang, X. Yuan, H. Wang, W. Mérida, H. Zhu, J. Shen, S. Wu, J. Zhang, International Journal of Hydrogen Energy 34 (2009) 388e404.

[116] W. Schmittinger, A. Vahidi, Journal of Power Sources 180 (2008) 1e14. [117] P. Rama, R. Chen, J. Andrews, Proceedings of the Institution of Mechanical

Engineers, Part A: Journal of Power and Energy 222 (2008) 421e441.

[118] J. Wu, X.Z. Yuan, J.J. Martin, H. Wang, J. Zhang, J. Shen, S. Wu, W. Merida, Journal of Power Sources 184 (2008) 104e119. 
[119] Y. Zhai, H. Zhang, G. Liu, J. Hu, B. Yi, Journal of The Electrochemical Society 154 (2007) B72eB76.

[120] G. Liu, H. Zhang, J. Hu, Y. Zhai, D. Xu, Z.-g . Shao, Journal of Power Sources 162 (2006) 547e552.

[121] S. Yu, L. Xiao, B.C. Benicewicz, Fuel Cells 8 (2008) $165 e 174$.

[122] C. Wannek, B. Kohnen, H.F. Oetjen, H. Lippert, J. Mergel, Fuel Cells 8 (2008) $87 \mathrm{e} 95$.

[123] P. Moçotéguy, B. Ludwig, J. Scholta, Y. Nedellec, D.J. Jones, J. Rozière, Fuel Cells 10 (2010) $299 \mathrm{e} 311$.

[124] H.L. Lin, Y.S. Hsieh, C.W. Chiu, T.L. Yu, L.C. Chen, Journal of Power Sources 193 (2009) $170 \mathrm{e} 174$.

[125] X. Cheng, J. Zhang, Y. Tang, C. Song, J. Shen, D. Song, J. Zhang, Journal of Power Sources 167 (2007) 25e31.

[126] C. Bonnet, S. Didierjean, N. Guillet, S. Besse, T. Colinart, P. Carré, Journal of Power Sources 182 (2008) 441e448.

[127] D. Chu, R. Jiang, Journal of Power Sources 80 (1999) $226 e 234$.

[128] K.S. Dhathathreyan, P. Sridhar, G. Sasikumar, K.K. Ghosh, G. Velayutham,

N. Rajalakshmi, C.K. Subramaniam, M. Raja, K. Ramya, International Journal of Hydrogen Energy 24 (1999) 1107e1115.

[129] S. Pandiyan, K. Jayakumar, N. Rajalakshmi, K.S. Dhathathreyan, International Journal of Heat and Mass Transfer 51 (2008) $469 e 473$.

[130] P. Rodatz, F. Büchi, C. Onder, L. Guzzella, Journal of Power Sources 128 (2004) $208 \mathrm{e} 217$.

[131] R. Eckl, W. Zehtner, C. Leu, U. Wagner, Journal of Power Sources 138 (2004) $137 \mathrm{e} 144$.

[132] M. Miller, A. Bazylak, Journal of Power Sources 196 (2011) 601e613.

[133] F. Urbani, O. Barbera, G. Giacoppo, G. Squadrito, E. Passalacqua, International Journal of Hydrogen Energy 33 (2008) 3137e3141.

[134] J.I. San Martin, I. Zamora, J.J. San Martin, V. Aperribay, E. Torres, P. Eguia, Energy 35 (2010) $1898 \mathrm{e} 1907$.

[135] S. Giddey, F.T. Ciacchi, S.P.S. Badwal, Journal of Power Sources 125 (2004) $155 \mathrm{e} 165$.

[136] C. Tori, M. Baleztena, C. Peralta, R. Calzada, E. Jorge, D. Barsellini, G. Garaventta, A. Visintin, W.E. Triaca, International Journal of Hydrogen Energy 33 (2008) 3588e3591.

[137] A.J. del Real, A. Arce, C. Bordons, Journal of Power Sources 173 (2007) $310 e 324$. [138] A. Heinzel, F. Mahlendorf, O. Niemzig, C. Kreuz, Journal of Power Sources 131 (2004) 35e40.

[139] O.J. Murphy, A. Cisar, E. Clarke, Electrochimica Acta 43 (1998) 3829e3840. [140] J. Hamelin, K. Agbossou, A. Laperrière, F. Laurencelle, T.K. Bose, International Journal of Hydrogen Energy 26 (2001) 625e629.

[141] J. Clement, X. Wang, Applied Thermal Engineering 50 (2013) 268e274. [142] J. Scholta, M. Messerschmidt, L. Jörissen, C. Hartnig, Journal of Power Sources 190 (2009) $83 \mathrm{e} 85$. 
[143] A. Bazylak, International Journal of Hydrogen Energy 34 (2009) 3845e3857. [144] X.G. Li, M. Sabir, International Journal of Hydrogen Energy 30 (2005) $359 \mathrm{e} 371$.

[145] S.J. Andreasen, S.K. Kær, International Journal of Hydrogen Energy 33 (2008) $4655 \mathrm{e} 4664$.

[146] A. Friedl, S.D. Fraser, W.R. Baumgartner, V. Hacker, Journal of Power Sources 185 (2008) 248e26o.

[147] S. Banerjee, D.E. Curtin, Journal of Fluorine Chemistry 125 (2004) 1211e 1216.

[148] C. Iojoiu, F. Chabert, M. Maréchal, N.E. Kissi, J. Guindet, J.Y. Sanchez, Journal of Power Sources 153 (2006) 198e209.

[149] K. Miyatake, B. Bae, M. Watanabe, Polymer Chemistry, 2011, UK. [150] J. Parvole, P. Jannasch, Macromolecules 41 (2008) 3893e3903.

[151] G.B. Ye, K. Li, C.A. Xiao, W. Chen, H.N. Zhang, M. Pan, Journal of Applied Polymer Science 120 (2011) 1186e1192.

[152] Z.B. Wang, H.L. Tang, M. Pan, Journal of Membrane Science 369 (2011) $250 e 257$. [153] D.M. Xing, G.H. He, Z.J. Hou, P.W. Ming, S.F. Song, International Journal of Hydrogen Energy 36 (2011) 2177e2183.

[154] T. Sancho, J. Soler, M.P. Pina, Journal of Power Sources 169 (2007) 92e97. [155] M. Amirinejad, S.S. Madaeni, E. Rafiee, S. Amirinejad, Cesium hydrogen salt of

heteropolyacids/Nafion nanocomposite membranes for proton exchange membrane fuel cells, Journal of Membrane Science 377 (2011) $89 e 98$.

[156] D.X. Luu, D. Kim, Journal of Membrane Science 371 (2011) 248e253.

[157] Y. Kozawa, S. Suzuki, M. Miyayama, T. Okumiya, E. Traversa, Solid State Ionics 181 (2010) 348e353.

[158] H. Pu, D. Wang, Z. Yang, Journal of Membrane Science 360 (2010) $123 \mathrm{e} 129$. [159] M.-S. Jun, Y.-W. Choi, J.-D. Kim, Journal of Membrane Science.

[160] J. Peron, A. Mani, X.S. Zhao, D. Edwards, M. Adachi, T. Soboleva, Z.Q. Shi, Z. Xie, T. Navessin, S. Holdcroft, Journal of Membrane Science 356 (2010) 44e51. [161] W. Liu, S.J. Wang, M. Xiao, D.M. Han, Y.Z. Meng, Chemical Communications 48 (2012) $3415 \mathrm{e} 3417$.

[162] M.M. Nasef, H. Saidi, K.M. Dahlan, Polymer International 60 (2011) 186e193. [163] L. Maldonado, J.C. Perrin, J. Dillet, O. Lottin, Journal of Membrane Science 389 (2012) $43 \mathrm{e} 56$.

[164] H. Namazi, H. Ahmadi, Journal of Power Sources 196 (2011) 2573e2583. [165] C. Liang, C. Nagami, T. Maruyama, T. Sotani, H. Matsuyama, Journal of Applied Polymer Science 109 (2008) 3739e3745.

[166] S.E. Nam, S.O. Kim, Y. Kang, J.W. Lee, K.H. Lee, Journal of Membrane Science 322 (2008) 466e474.

[167] J.J. Yuan, H.T. Pu, Z.L. Yang, Journal of Polymer Science Part A-Polymer Chemistry 47 (2009) 2647e2655.

[168] H. Zarrin, Y. Jun, M. Fowler, Z. Chen, Abstract \#643, 219th ECS Meeting, (C) 2011, The Electrochemical Society, 2011.

[169] M. Casciola, D. Capitani, A. Comite, A. Donnadio, V. Frittella, M. Pica, M. Sganappa, A. Varzi, Fuel Cells 8 (2008) 217 e224. 
[170] Y.T. Kim, K.H. Kim, M.K. Song, H.W. Rhee, Current Applied Physics 6 (2006) $612 \mathrm{e} 615$.

[171] E. Fontananova, F. Trotta, J.C. Jansen, E. Drioli, Journal of Membrane Science 348 (2010) 326e336.

[172] G. Frutsaert, G. David, B. Ameduri, D.J. Jones, J. Roziere, X. Glipa, Journal of Membrane Science 367 (2011) 127e133.

[173] X.H. Ye, H. Bai, W.S.W. Ho, Journal of Membrane Science 279 (2006) 5700577.

[174] K. Miyatake, T. Yasuda, M. Hirai, M. Nanasawa, M. Watanabe, Journal of Polymer Science Part A-Polymer Chemistry 45 (2007) 157e163.

[175] B. Bae, T. Yoda, K. Miyatake, H. Uchida, M. Watanabe, Angewandte Chemieinternational Edition 49 (2010) 317e320.

[176] Q.F. Li, H.C. Rudbeck, A. Chromik, J.O. Jensen, C. Pan, T. Steenberg, M. Calverley, N.J. Bjerrum, J. Kerres, Journal of Membrane Science 347 (2010) $260 e 270$. [177] H.S. Lee, A. Roy, O. Lane, J.E. McGrath, Polymer 49 (2008) 5387e5396. [178] G. Lakshminarayana, M. Nogami, I.V. Kityk, Energy 35 (2010) $5260 e 5268$.

[179] G. Lakshminarayana, R. Vijayaraghavan, M. Nogami, I.V. Kityk, Journal of The Electrochemical Society 158 (2011) B376eB383.

[18o] G. Lakshminarayana, M. Nogami, I.V. Kityk, Journal of Alloys and Compounds 509 (2011) 2238e2242.

[181] N.N. Krishnan, H.-J. Lee, H.-J. Kim, J.-Y. Kim, I. Hwang, J.H. Jang, E.A. Cho, S.-K. Kim, D. Henkensmeier, S.-A. Hong, T.-H. Lim, European Polymer Journal 46 (2010) $1633 \mathrm{e} 1641$. 